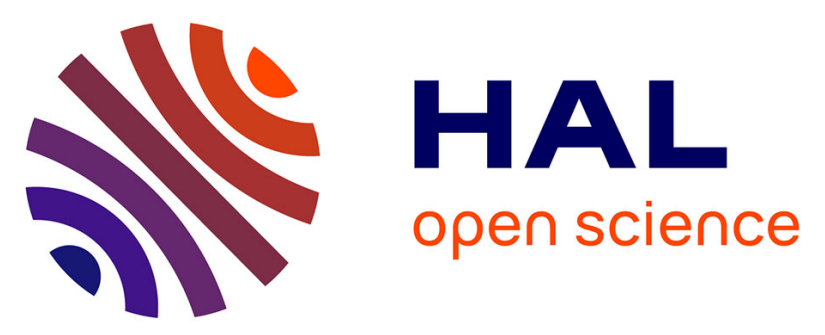

\title{
Effects of DEHP on post-embryonic development, nuclear receptor expression, metabolite and ecdysteroid concentrations of the moth Spodoptera littoralis
}

Amandine Aviles, Isabelle Boulogne, Nicolas Durand, Annick Maria, Alexandra Cordeiro, Françoise Bozzolan, Aurélie Goutte, Fabrice Alliot, Matthieu Dacher, David Renault, et al.

\section{To cite this version:}

Amandine Aviles, Isabelle Boulogne, Nicolas Durand, Annick Maria, Alexandra Cordeiro, et al.. Effects of DEHP on post-embryonic development, nuclear receptor expression, metabolite and ecdysteroid concentrations of the moth Spodoptera littoralis. Chemosphere, 2019, 215, pp.725-738. 10.1016/j.chemosphere.2018.10.102 . hal-01899941

\section{HAL Id: hal-01899941 https://hal.science/hal-01899941}

Submitted on 9 Nov 2018

HAL is a multi-disciplinary open access archive for the deposit and dissemination of scientific research documents, whether they are published or not. The documents may come from teaching and research institutions in France or abroad, or from public or private research centers.
L'archive ouverte pluridisciplinaire HAL, est destinée au dépôt et à la diffusion de documents scientifiques de niveau recherche, publiés ou non, émanant des établissements d'enseignement et de recherche français ou étrangers, des laboratoires publics ou privés. 
Effects of DEHP on post-embryonic development, nuclear receptor expression, metabolite and ecdysteroid concentrations of the moth Spodoptera littoralis

Amandine AVILES ${ }^{1}$, Isabelle BOULOGNE ${ }^{1,3}$, Nicolas DURAND ${ }^{1}$, Annick MARIA ${ }^{1}$, Alexandra CORDEIRO $^{1}$, Françoise BOZZOLAN ${ }^{1}$, Aurélie GOUTTE ${ }^{4}$, Fabrice ALLIOT $^{4}$, Matthieu DACHER $^{1,2}$, David RENAULT ${ }^{5,6}$, Martine MAIBECHE ${ }^{1}$, David SIAUSSAT ${ }^{1}$

Author affiliations:

${ }^{1}$ Sorbonne Université, INRA, CNRS, IRD, UPEC, Univ. P7, Institut d'Ecologie et des Sciences de l'Environnement de Paris (iEES-Paris), F75005 Paris, France

${ }^{2}$ Sorbonne Université, INRA, CNRS, IRD, UPEC, Univ. P7, Institut d'Ecologie et des Sciences de l'Environnement de Paris (iEES-Paris), 78026 Versailles, France

${ }^{33}$ Normandie Université, UNIROUEN, Laboratoire Glyco-MEV EA 4358, Fédération de

Recherche "Normandie Végétal" FED 4277, 76000 Rouen, France

${ }^{4}$ École Pratique des Hautes Études (EPHE), PSL Research University. UMR 7619 METIS,

Sorbonne Université (Paris, France)

${ }^{5}$ Université de Rennes 1, UMR CNRS 6553 Ecobio, 263 Avenue du Gal Leclerc, CS 74205, 35042

Rennes Cedex, France

${ }^{6}$ Institut Universitaire de France, 1 Rue Descartes, Paris, France

Corresponding author:

Institut d'Ecologie et Sciences de l'Environnement de Paris - Département Ecologie Sensorielle

Email address: david.siaussat@sorbonne-universite.fr

Present address: Sorbonne Université, 4 place Jussieu, Campus Pierre et Marie Curie - Tours 44-45, $3^{\text {ème }}$ étage, boite courrier 237, 75005 Paris (France)

\begin{abstract}
:
Di (2-ethylhexyl) phthalate (DEHP) is recognized in vertebrates as an Endocrine Disrupting Chemical (EDC). DEHP can alter steroid hormones production, development, reproduction and behavior in vertebrates. Only few studies investigated DEHP effects on insects. However, some recent studies on aquatic insects showed that DEHP could also act as an EDC by interfering with the signaling pathways of ecdysteroids, the main hormones involved in the control of insect postembryonic development and physiology. The aim of the study was to investigate (1) the fate of DEHP within a terrestrial insect species by exposing larvae to food containing a wide range of DEHP concentrations and (2) the effects of this chemical on their post-embryonic development and metamorphosis, by using a multi-level approach. DEHP was shown to be present both in larvae and resulting stages, with higher concentrations in chrysalises and adults than in larvae. DEHP concentrations also decreased at the end of the last larval instar, suggesting the metabolic transformation or excretion of this chemical during this time. Only the two highest DEHP doses induced higher insect mortality, whereas low and intermediate concentrations increased larval food consumption without affecting body weight. Metabolic profiles showed that in control insects, the last three days before metamorphosis correspond to a metabolic transition, but with time-dependent changes in treated insects. Interestingly, DEHP treatments also alter both hemolymphatic ecdysteroid titers and expression levels of ecdysteroid response genes. These results confirm that DEHP can alter insect post-embryonic development and metamorphosis, by interfering with ecdysteroid pathways.
\end{abstract}

Keywords: Bis(2-ethylhexyl)phthalate, metabolic profiling, insect, environmental pollution, development

\title{
Introduction
}


Endocrine disrupting compounds (EDCs) are chemicals that interfere with the body's endocrine system, and produce adverse developmental, reproductive, neurological and/or immune effects in both humans and wildlife (Matthiessen et al., 2018). EDCs encompass a wide range of chemical substances, including pharmaceuticals, pesticides and plastic compounds. Among plastic compounds, $\operatorname{Di}(2$-ethylhexyl) phthalate (DEHP) is produced in very high quantities and found in many mass-produced products including medical devices, food packaging, perfumes, cosmetics, flooring materials (Bauer \& Herrmann 1997; Staples et al., 2002; Andrady \& Neal 2009). DEHP can be easily released in the environment since it is not covalently bound to plastic, and adheres to organic particles (Zeng et al., 2008; Magdouli et al., 2013). As a result, DEHP is widely dispersed in the environment via sewage systems, waste disposals and sprayings (Fromme et al., 2002; Porter \& Janz, 2003; Wang et al., 2011; Casals-Casas \& Desvergne, 2011). Moreover, DEHP can be transported over long distances. As the chemical degradation of DEHP is practically null in natura, many - if not all - organisms can be in contact with this compound during their life (Wofford et al., 1981).

Aquatic or terrestrial organisms are contaminated by direct exposure to DEHP, or by ingestion of DEHP-contaminated food (Guehlstorf, 2004; Bar-El \& Reifen, 2010). In vertebrates, DEHP disturbs the levels of circulating hormones, as well as the hormone-receptor interaction and the steroid signalling pathways (Wetherill et al., 2007; Stoker et al., 2008; Vanderberg et al., 2009). These disruptions can lead to dysregulations of several processes including metabolic disruption reported in goldfish or in rat cardiac cells (Jordan et al., 2012; Posnack et al., 2012).

In invertebrates, and more particularly in insects, the impact of DEHP has been poorly investigated despite the crucial role of these animals in ecology, agronomy, medicine and economy (deFur et al., 1999; Oehlmann \& Schulte-Oehlmann, 2003). Moreover, most studies have focused on the impact of EDCs on aquatic insects, such as Chironomus riparius (Planello et al., 2011; Herrero et al. 2017), a common ecotoxicological model. There are few studies that have been conducted on terrestrial insects. One study on the ant Lasius niger reported a reduction of egglaying rate in queens exposed to DEHP, together with an activation of their immune system (Cuvillier-Hot et al., 2014). Drosophila melanogaster contaminated by DEHP exhibited a life span reduction and a modulation of cholinergic transmission in their projection neurons (Ran et al., 2012). The mode of action of DEHP in insects is still not yet well understood. It has been suggested that DEHP can disrupt the concentration of circulating hormones, such as ecdysteroids, or interfere with hormone receptors, leading to the activation of inappropriate steroid signalling pathway (Hanioka et al., 2008, Planelló et al., 2011; Tarrant et al., 2011). Since these hormones control many developmental processes, such as moulting, metamorphosis (Siaussat et al., 2008) and reproductive physiology (Bigot et al., 2012), endocrine disruption could have important consequences.

Soils and water contaminations by DEHP in agricultural ecosystems are now reported and can reach quite high concentrations: e.g. up to $300-500 \mu \mathrm{g} / \mathrm{L}$ for surface and underground water and up to $30 \mathrm{mg} / \mathrm{kg}$ for agricultural soils (Zeng et al., 2008; Uren-Webster et al, 2010; Planello et al., 2011; Wang et al., 2017). In sludge potentially used to fertilize agricultural soils, DEHP reaches concentrations ranging from 150 to $600 \mathrm{mg} / \mathrm{kg}$ dry weight (dw) (Bergé et al., 2013), with subsequent bioaccumulation into cultivated plants (EU, 2008; Sun et al., 2015). Several studies highlighted DEHP accumulation in cultivated plants with a range of concentration going from 0.1 to $4150 \mu \mathrm{g}$ of DEHP per gram of plant or leaf (i.e. dry weight) and from 26.5 to $362 \mu \mathrm{g}$ of DEHP per gram of peel and flesh of three fruits (He et al. 2016; Zhao et al. 2015; Wu et al. 2013; Fu \& Du, 2011; Du et al. 2010; Du et al., 2006). Herbivorous insects are likely to ingest DEHP when feeding on cultivated plants (Staples et al., 2010). In the present study, we therefore used the highly polyphagous and widespread insect species, the Egyptian cotton leafworm Spodoptera littoralis (Boisduval) (Lepidoptera: Noctuidae) as a model to investigate the effects of DEHP on the biology and physiology of a terrestrial insect.

This study was designed in order to answer the following questions: (1) What are the consequences of continuous ingestion of DEHP-contaminated food in terms of bioaccumulation in S. littoralis? (2) What are the effects of this treatment on post-embryonic development? (3) Does 
DEHP disrupt the molecular events that occur during the last larval stage (critical stage before the passage to chrysalis)? (4) Considering the known effects of the EDCs, does DEHP exposure induce effects at multiple levels (e.g. gene expression, metabolism, hormonal concentration) in $S$. littoralis?

To address these questions, we first monitored the effects of DEHP ingestion on the postembryonic development of $S$. littoralis by analysing several key parameters, such as the duration of larval stages, larval weight, and sex ratio. In parallel, we measured DEHP concentrations at all stages of the life cycle. Then, we focused on the $5^{\text {th }}, 6^{\text {th }}$ and $7^{\text {th }}$ days of the last instar, a crucial period preceding the pupal stage and the metamorphosis. The expression levels of four nuclear receptors involved in the ecdysteroid signalling pathway were measured: EcR, the 20hydroxyecdysone (20E) receptor; Ultraspiracle (USP), its heterodimeric partner and two early-late genes, E75A/B and E75D. We also measured ecdysteroid hemolymphatic concentrations and drew a physiological footprint of DEHP effects by running metabolomics assays.

\section{Material and methods}

\section{Insect rearing, DEHP treatment and study of the post-embryonic development}

S. littoralis larvae were reared on a semi-artificial diet (stored in glass jars at $4{ }^{\circ} \mathrm{C}$ prior to use) from the third instar to pupation at $23^{\circ} \mathrm{C}, 60 \%-80 \%$ relative humidity, and 16:8h light:dark cycle (Hinks \& Byers, 1976). Six environmentally relevant concentrations (100pg; 1ng; 10ng; 100ng; $1 \mu \mathrm{g}$ and $10 \mu \mathrm{g}$ per gram of food) and three high concentrations $(500 \mu \mathrm{g}, 5 \mathrm{mg}$ and $40 \mathrm{mg}$ per gram of food) of DEHP (PESTANAL $® 36735$, Sigma, France) were added to the diet. Control larvae were reared on food containing only the solvent $(0.5 \%$ pure Ethanol, absolute, PROLABO®, VWR, France). Larval mass, food consumption and mortality rate were monitored daily. The presence of a cephalic capsule was checked every day in order to determine the instar duration, and the beginning of ecdysis. Male and female chrysalises were kept separately in order to determine the pupal stage duration, the sex-ratio and the percentage of mortality.

\section{Measure of DEHP content \\ Sample Treatment}

It is important to realize DEHP is present in the environment. Thus, the DEHP treatments administrated to the animals underestimate the real level of contamination. As a result, we estimated the actual level of contamination. DEHP content was measured in several treated and control larvae, pupae (from 4 to 6 days-old) and adults ( 2 days-old). Considering the atmospheric contamination in our lab conditions, as described by Lenoir et al. (2012), we also measured the concentration in control and contaminated food (100 pg/g, 1ng/g, 100ng/g, 10 $\mathrm{gg} / \mathrm{g}$ and 5mg/g) and realized a linear regression analysis between theoretical applied concentrations and actual measured concentrations in order to indicate directly in the figures the measured concentrations or estimated by the linear regression (see results). Since the concentration measured in food for the $1 \mathrm{ng} / \mathrm{g}$ condition was similar to the control one, we subsequently performed the measurement of DEHP contents only for the insects treated with 100ng, $10 \mu \mathrm{g}$ and $5 \mathrm{mg} / \mathrm{g}$ contaminated diet, and their controls (see results). Before treatment, artificial diet and whole $S$. littoralis adult males and females were stocked at -18 ${ }^{\circ} \mathrm{C}$, lyophilized and crushed in a mortar. Samples, $0.2 \mathrm{~g} \mathrm{dw}$, were spiked with an internal standard (IS) (DEHP-d4: $2 \mu \mathrm{g}$ ) in a $40 \mathrm{~mL}$ centrifuge glass tube overnight at $4{ }^{\circ} \mathrm{C}$. The next day, samples were extracted with $15 \mathrm{~mL}$ of hexane/acetone $(50 / 50[\mathrm{v} / \mathrm{v}])$ in a Bransonic ultrasonic bath during $20 \mathrm{~min}$ (US-EPA method 3550B for ultrasonic extraction 1996). Extracts were centrifuged (2 min at 4500 $\mathrm{rpm}$ ), and supernatants were kept. This procedure was performed twice, and both extracts were combined before concentration with EZ-2 system and finally under a nitrogen stream. The clean-up procedure, derived from USEPA method 3620B (for phthalate ester and PCB fraction cleanup), consisted of partitioning on a Florisil cartridge (Supelco [1 g]). After conditioning, loading extract and washing with $10 \mathrm{~mL}$ of hexane, DEHP was eluted with $10 \mathrm{~mL}$ of hexane/acetone $(90 / 10[\mathrm{v} / \mathrm{v}])$. 
The extract was concentrated $(400 \mu \mathrm{L})$ under a nitrogen stream and deposited in injection vial before analysis.

\section{Analytical Conditions}

Analyses were performed by gas chromatography-mass spectrometry (GC-MS) with a 7890 A gas chromatograph coupled to a 5975 A mass spectrometer (Agilent Technologies, Les Ulis, France). Analytical conditions are summarized in Table S1.

\section{Validation method}

In our experiment, instrument detection limits (IDLs), i.e concentration of DEHP in the standard solutions corresponding to a signal to noise ratio (SNR; peak to peak) of 3 , was of $2 \mathrm{pg}$ DEHP. Method detection limits (MDLs), corresponding to the concentration of spiked sample for a SNR (peak to peak) of 9, was of 46ng DEHP/g (dw). Finally, recoveries for the entire procedure were estimated by the determination of recovery rate (RR), which was $84 \%$ in our experiment. Simultaneously to each set of analyses $(n=10)$, method blanks were performed.

\section{RNA isolation and cDNA synthesis}

Larvae were sampled on day 5, 6 and 7 of the last instar, and stored at $-80{ }^{\circ} \mathrm{C}$ until total RNAs extraction by TRIzol method (Invitrogen, Carlsbad, CA, USA) coupled to RNAeasy kit extraction (Qiagen, USA). RNA quality was checked by spectrophotometry at 260nm and 280nm (BioPhotometer, Eppendorf, Hamburg, Germany). Treatment with DNase I (Roche, USA) was made in accordance with the manufacturer's instructions. Single-stranded cDNAs were synthesized from $5 \mu \mathrm{g}$ of RNA with Superscript II reverse transcriptase (Invitrogen) using the manufacturer's protocol. For each experimental condition, four to five biological replicates were performed.

\section{PCR and qPCR}

Five genes were first tested as putative housekeeping genes (actin, ATPase, Rpl13, tubulin and ubiquitin) by Bestkeeper analysis (Pfaffl et al. 2004). Rpl13 (GenBank FJ979921) was used as the reference gene, as it had the most stable expression level among experimental groups. Forward and reverse primers for housekeeping and candidate genes (ECR, USP, E75A/B, E75D) (Supplementary data Table S2) were designed from EST library sequences using EPRIMER 3 software, as described in Bigot et al. (2012). Since the isoforms A and B of E75 have few amino acid differences in their N-terminal parts, primers were designed in a common region, allowing the accurate amplification of the two isoforms. PCR reactions were performed on the LightCycler480 Real-Time PCR Detection System (Roche Applied Science, France), adapted from Bigot et al. (2012). Each reaction consisted of $5 \mu \mathrm{L}$ of Absolute Blue SYBR Green Fluor (Thermo Scientific, Waltham, MA, USA), $4 \mu \mathrm{L}$ cDNA $(6.25 \mathrm{ng} / \mu \mathrm{L})$ and $0.5 \mu \mathrm{L}$ of each primer $(10 \mu \mathrm{M})$. The PCR program consisted of an initial step at $95^{\circ} \mathrm{C}$ for $5 \mathrm{~min}$, followed by 50 cycles, each comprising $10 \mathrm{~s}$ at $95{ }^{\circ} \mathrm{C}, 15 \mathrm{~s}$ at $60{ }^{\circ} \mathrm{C}$, and $15 \mathrm{~s}$ at $72{ }^{\circ} \mathrm{C}$. Under these conditions, a single and discrete peak was detected for all primers tested, and all primers gave efficiencies of 90-100\%. Each run included the fivefold dilution series, the candidate genes, the reference gene, and negative controls. The average $\mathrm{C}_{\mathrm{t}}$ value of each triplicate reaction was used to normalize the candidate gene expression level to the geometric mean of Rpl13 level in Q-Gene (Simon, 2003).

\section{Hemolymph collection}

Larvae were sampled on day 5, 6 and 7 of the last instar. Hemolymph was collected by piercing the dorsal cuticle and epidermis with a sterile scalpel blade. The drop of hemolymph obtained from 1 to 4 individuals (for a total of $40 \pm 10 \mu \mathrm{L}$ ) was stored at $-20{ }^{\circ} \mathrm{C}$ with $250 \mu \mathrm{L}$ of methanol (purity $99.9 \%$, MERCK, France) for ecdysteroid titration, or at $-20{ }^{\circ} \mathrm{C}$ with $400 \mu \mathrm{L}$ of ethanol (purity 99.9\%, MERCK, France) for metabolomic profiling. 
Six to fifteen biological replicates were prepared for each experimental condition. After a centrifugation at 9,500 $\mathrm{g}$ for $10 \mathrm{~min}$, the supernatant was collected and dried under vacuum using a SpeedVac Concentrator (Eppendorf, France). Samples were dissolved in a buffer for an Enzyme Immuno Assay (EIA) adapted from Porcheron et al. (1989). The EIA titration was made using a polyclonal anti-20E antiserum L2 (dilution 1:62,500) and a 2-Succinyl-20-hydroxyecdysone coupled to peroxidase (dilution 1:100,000). O-Phenylenediamine, OPD and hydrogen peroxide solution tablets (OPD, Sigma, France) were used for the chromogenic reaction and optical density (OD) was measured at $450 \mathrm{~nm}$. Calibration curves were produced for L2 antiserum using 20E (range from 16 - 2000 fmol; gift from René Lafont, UPMC, Paris, France) and data were expressed as pg $20 \mathrm{E}$ equivalent $/ \mu \mathrm{L}$ of hemolymph.

\section{Metabolomic profiling}

Ten biological replicates were prepared for each experimental condition, as described in Khodayari et al. (2013). The samples were homogenized in $600 \mu \mathrm{L}$ of methanol-chloroform (2:1) using a bead-beating device (Retsch ${ }^{\mathrm{TM}}$ MM301, RetschGbmH, Haan, Germany). A volume of 400 $\mu \mathrm{L}$ of ice-cold ultrapure water was added to each sample, before centrifugation at 4,000 $\mathrm{g}$ for 10 min at $4{ }^{\circ} \mathrm{C}$. Then, aliquots $(300 \mu \mathrm{L})$ of the upper aqueous phase containing polar metabolites were transferred to microtubes and vacuum-dried. Following derivatization (see Khodayari et al., 2013 for the detailed procedure), metabolites were analyzed by gas chromatography-mass spectrometry (GC-MS), which included a CTC CombiPal autosampler (CTC Analytics AG, Zwingen, Switzerland), a Trace GC Ultra chromatograph, and a Trace DSQII quadruple mass spectrometer (Thermo Fischer Scientific Inc., Waltham, MA, USA) (Khodayari et al., 2013). Peaks were annotated using both mass spectra (two specific ions), and retention times. Calibration curves were set using standards consisting of 57 pure reference compounds most often quantified in insects with this equipement. Metabolite levels were quantified using XCalibur v2.0.7 software (Thermo Fisher Scientific Inc., Waltham, MA, USA).

\section{Statistical analysis}

Statistical analyses were performed using R 3.2.2 and R Studio 1.0 (R Core Team, 2015), JMP (SAS institute, France) and XLstat software (Addinsoft, France). Shapiro-Wilk test was used to check the normality of the data, and a Bartlett's test was used for testing the homogeneity of the variance. Sex-ratio was analyzed by comparison of proportions with a bilateral test (Monte Carlo method). Larval body mass changes and food consumption were analyzed with the Dunnet's Test using control animals as a reference group. Durations of larval and pupal developmental stages were analyzed with one-way ANOVA. Mortality rates during larval and pupal stages were analyzed with a logistic regression test. Hemolymphatic concentrations of ecdysteroids and DEHP were compared using a Wilcoxon sum of rank test. qPCR results were analyzed with an ANOVA and Student $t$ test. Metabolomic results were analyzed using ANOVA and Student $t$ test for data respecting the conditions for parametric tests (Variance and normality) or using a Wilcoxon test for the others. In all cases, p-values lower than $5 \%$ were considered significant.

\section{Results}

\section{DEHP contents in diet}

Control diet contained an average of $392 \pm 125$ ng of DEHP per g (fresh weight) (Figure 1A). This value was similar to the diet spiked with DEHP at $100 \mathrm{pg} / \mathrm{g}$ and $1 \mathrm{ng} / \mathrm{g}$ of food (i.e. $443 \pm 138$ and $676 \pm 160 \mathrm{ng} / \mathrm{g}$ ) and this amount would be considered as a threshold of atmospheric contamination. Concentrations of DEHP were significantly higher for diets treated with $100 \mathrm{ng}, 10$ $\mu \mathrm{g}$ and lower for diet treated with $5 \mathrm{mg} \mathrm{DEHP/g}$ (Figure 1; Wilcoxon test, $\mathrm{P}<0.01$ ), with values of $1.1 \pm 0.225 \mu \mathrm{g}, 19.7 \pm 1.9 \mu \mathrm{g}$, and $4.3 \pm 0.229 \mathrm{mg} \mathrm{DEHP} / \mathrm{g}$, respectively. These measured values were 
thus used as references for the rest of the study, instead of the theoretical ones (Figure 1B). The lacking values (i.e. for the theoretical values: $1 \mu \mathrm{g}, 500 \mu \mathrm{g}$ and $40 \mathrm{mg}$ ) were determinated by a linear regression analysis using the measured values (Figure 1B). For the control, $1.1 \mu \mathrm{g}$ and $19.7 \mu \mathrm{g} / \mathrm{g}$ conditions, we observed that DEHP contents were
higher in pupae and adults in comparison to larval stages (Figure 2, statistical results not represented, Wilcoxon test, $\mathrm{P}<0.05)$. Conversely, a significant higher DEHP content was observed in L5 and L6 larval instar fed with the highest concentration (i.e. $4.3 \mathrm{mg} / \mathrm{g}$ ) in comparison to pupal and adult stage (Figure 2, statistical results not represented, Wilcoxon test, $\mathrm{P}<0.05$ ).

The focus on each stage highlighted that we observed most of the time a significant higher DEHP content in all stages corresponding to the $4.3 \mathrm{mg} / \mathrm{g}$ condition in comparison to control and others conditions (Figure 2, Wilcoxon test, $\mathrm{P}<0.05$, see first uppercase letters). But we noted an exception for the female pupae for which the DEHP content for the $4.3 \mathrm{mg} / \mathrm{g}$ condition was not significantly different to control (Figure 2, Wilcoxon test, $\mathrm{P}<0.05$, see first uppercase letters). Most of the time the DEHP content measured in treated groups was similar to control (i.e. no statistical difference) or higher to control content (Figure 2, Wilcoxon test, $\mathrm{P}<0.05$, see first uppercase letters). Female pupae presented an exception since the DEHP content in $1.1 \mu \mathrm{g}$ female pupae was significantly lower to control (Figure 2, Wilcoxon test, $\mathrm{P}<0.05$, see first uppercase letters).

When focusing only on the larval stage, a specific pattern was observed with a significant decrease of DEHP concentration between the L6 and L7 for all DEHP conditions (Figure 2, Wilcoxon test, $\mathrm{P}<0.05$, see second lowercase letters). Differences in DEHP concentrations appeared also between the males and the females. Thus, control female pupae have a significant higher DEHP content in comparison to males (Figure 2, Wilcoxon test, $\mathrm{P}<0.05$, see second lowercase letters), whereas female pupae treated with $1.1 \mu \mathrm{g} / \mathrm{g}$ have a significant lower DEHP content in comparison to males of the same DEHP concentration (Figure 2, Wilcoxon test, $\mathrm{P}<0.05$, see second lowercase letters). A similar pattern was observed for adults with a higher DEHP content in control females and lower concentrations for all treated females in comparison to males (Figure 2, Wilcoxon test, $\mathrm{P}<0.05$, see second lowercase letters). Thus, our results highlighted that management of DEHP appears to be different in males and females.

\section{Impact of DEHP on post-embryonic development}

The highest concentration of DEHP induced a high mortality from the fourth to the seventh instar, leading to the death of all larvae at the time of the pupation (Figure 3; logistic regression test, $\mathrm{P}<0.001$ for all larval stages). High mortality was also observed for larvae fed with DEHP at 4.3 $\mathrm{mg} / \mathrm{g}$, with a cumulative mortality of $30 \%$ at L7 and $36 \%$ at pupal stage (Figure 3; logistic regression test, $\mathrm{P}<0.01$ for all larval stages).

We then analyzed the effects of DEHP on post-embryonic development time by exposing larvae to various DEHP concentrations in their diet. The highest DEHP concentration increased the duration of the fourth, fifth and sixth instars (L4, L5, L6) (Figure 4; ANOVA F10, 464=1.02, $\mathrm{P}<0.0425$ with Tukey HSD test $\mathrm{P}<0.05$ to 0.001 for L4; ANOVA F10,468=1.996, $\mathrm{P}<0.0321$ with Tukey HSD test $\mathrm{P}<0.05$ to 0.001 for L5; ANOVA F10,477=15.52, $\mathrm{P}<2 \mathrm{e}-16$ with Tukey HSD test $\mathrm{P}<0.05$ to 0.001 for L6). The duration of the pupal stage was longer for the larvae treated with $19.7 \mu \mathrm{g}$ and $447.2 \mu \mathrm{g}$ of DEHP per $\mathrm{g}$ of diet, but without changes in larval stages (Figure 4; ANOVA F10,519=24.68, $\mathrm{P}<2 \mathrm{e}-16$ with Tukey HSD test $\mathrm{P}<0.05$ to 0.001$)$. Globally, by cumulating durations of larval and pupal stages (Figure 4, histogram named "Total"), we observed a significant increase in the postembryonic development time for larvae exposed to $3.2 \mu \mathrm{g}, 19.7 \mu \mathrm{g}$, $447.2 \mu \mathrm{g}$ and $4.3 \mathrm{mg} / \mathrm{g}$ of DEHP (Figure 4). Finally, sex ratio was modified at $3.2 \mu \mathrm{g} \mathrm{DEHP} / \mathrm{g}$ (Figure 5; Bilateral test with Monte Carlo method, $\mathrm{P}<0.05$ to 0.01 ): the percentage of females was increased $(56.2 \pm 4.8 \%)$ in comparison to control pupae $(48.5 \pm 3.7 \%)$.

DEHP treatment had no effect on larval mass gain of the surviving larvae, as compared with control larvae, except for larvae that were exposed to the highest DEHP concentration $(19.5 \mathrm{mg} / \mathrm{g}$ ) (Figure 6). In this latter group, the larvae grew more slowly, reaching a body mass two times lower than their control relatives at day 12 (Figure 6A, Dunnett's Test, $\mathrm{P}<0.05$ to 0.001 ). At this DEHP 
CCEPTED MANUSCRIPI

concentration, the surviving larvae reached the same body mass than the controls just before pupation. From the middle of the 6th larval instar till pupation, the increase of food consumption was slower for larvae grown on the $19.5 \mathrm{mg} / \mathrm{g}$ DEHP diet, as compared with control larvae (Figure 6B, Dunnett's Test, $\mathrm{P}<0.05$ to 0.001). For all other experimental conditions with DEHP, the increase of food consumption during the last larval instar was higher than in control larvae (Figure 6B, Dunnett's Test, $\mathrm{P}<0.001$ to 0.05$)$.

\section{Hemolymphatic concentrations of ecdysteroids in larvae}

Larvae treated with DEHP at $1.1 \mu \mathrm{g} / \mathrm{g}, 19.7 \mu \mathrm{g} / \mathrm{g}$ and $4.3 \mathrm{mg} / \mathrm{g}$ and control larvae were sampled at day 5, 6 or 7 during the last instar in order to measure their ecdysteroid titration. A peak of ecdysteroids is usually observed during the last instar of Lepidoptera, before the onset of pupal stage and metamorphosis. Our results showed that this peak can be observed at day 6 of L7 in $S$. littoralis larvae for all conditions (Figure 7). At day 7, we observed that ecdysteroid concentrations were higher in larvae fed with the highest dose of DEHP than in those fed with the lowest one (Figure 7, Wilcoxon's test, $\mathrm{P}<0.05$ ).

\section{Expression levels of nuclear receptors during the last larval instar (L7)}

A DEHP-concentration dependent decrease in EcR-B gene transcription was observed at day 6. This decrease was significantly different for the highest concentration of DEHP (i.e. $4.3 \mathrm{mg} / \mathrm{g}$ ) (Figure 8, Student $t$ test, $\mathrm{P}<0.05$ ). USP gene expression was lower than in controls at days 5 and 6 for concentrations of DEHP in the diet of $19.7 \mu \mathrm{g} / \mathrm{g}$ and $4.3 \mathrm{mg} / \mathrm{g}$, and at day 7 for $19.7 \mu \mathrm{g} / \mathrm{g}$ (Figure 8, Student t test, $\mathrm{P}<0.05$ to 0.001 ). No difference was observed in E75A/B and E75D gene expression levels at days 5 and 6, while E75D gene expression was lower at day 7 in larvae fed on diet with $1.1 \mu \mathrm{g}$ DEHP, but higher at $4.3 \mathrm{mg} / \mathrm{g}$ (Student t test, $\mathrm{P}<0.05$ for all comparisons).

\section{Metabolomic profiling}

Forty-four metabolites were quantified from the hemolymph of S. littoralis larvae. A metabolic transition was observed from the $5^{\text {th }}$ to the $7^{\text {th }}$ day, with increased concentrations of a significant number of metabolites involved in glycolysis (glucose, glucose-6P), TCA cycle (citrate, fumarate, malate, succinate), pentose phosphate pathway (adonitol, ribose, sorbitol, xylitol), fatty acid biosynthesis (galacturonic acid, glycerol, inositol), gluconeogenesis (glucose and lactate), amino acid production (alanine, asparagine, aspartate, glutamate, isoleucine, leucine, lysine, phenylalanine, threonine, valine) and others metabolic processes (gluconolactone, pipecolic acid, putrescine, spermidine) (Figure 9 and supplementary data Table S3 for details). Some metabolites as GABA, glycerol-3P, glycine, proline, serine and trehalose had a different pattern with a decrease of hemolymphatic concentrations. Valine displayed also a unique pattern characterized by a transient decrease from day 5 to 6 , followed by an increase to higher concentrations at day 7 . The day-by-day comparison between DEHP treated larvae with control larvae highlighted effects of DEHP on the amounts of twenty metabolites (Table 1). No difference was observed between control and the DEHP-treated larvae at day 5. At the $6^{\text {th }}$ day, seventeen metabolites had a lower concentration in larvae fed with $1.1 \mu \mathrm{g} / \mathrm{g}$ of DEHP in comparison to control larvae (Table 1, Student $t$ test, $\mathrm{P}<0.05$ to 0.01 ). Several metabolites had similar profiles at the $6^{\text {th }}$ day for other 19.7 $\mu \mathrm{g} / \mathrm{g}$ of DEHP. Lower concentrations of alanine, citric acid, glycerol, putrescine, serine and valine in larvae fed with $19.7 \mu \mathrm{g} / \mathrm{g}$ of DEHP were also measured. Energetic disruption is induced by DEHP since, on the seventeen metabolites, four are involved in TCA cycle, two in glycolysis, one in gluconeogenesis and three in pentose phosphate pathway. Amino acids synthesis seemed the second main disrupted metabolic mechanism with the decrease of the concentration of eight amino acids. At the $7^{\text {th }}$ day, lactic acid presented a lower concentration in larvae fed with $4.3 \mathrm{mg} / \mathrm{g}$, while at the same treatment trehalose concentration increased. Whereas the concentration of some metabolites was modified only for one DEHP treatment (i.e. erythritol, galactose, GABA, inositol, malic acid, phenylalanine, pipecolic acid, xylitol), the concentration of several metabolites was 
similarly modified for two DEHP treatments, (i.e. alanine, citric acid, glyceric acid, glycerol, putrescine and valine).

\section{Discussion}

\section{Environmental contamination and bioaccumulation of DEHP in S. littoralis}

In this work, we aimed at investigating the effects of DEHP on the physiology of a terrestrial insect, by growing $S$. littoralis on DEHP-contaminated food. We first monitored the amount of DEHP present in control diet (i.e. $392 \pm 125 \mathrm{ng}$ of DEHP per $\mathrm{g}$ of diet fresh weight) and found that it was quite similar to the concentration found in the contaminated diet initially prepared to reach a theoretical concentration of $1 \mathrm{ng} / \mathrm{g}$ of DEHP. This result shows that the environmental pollution should be measured to determine the basic level of contaminant during experimental procedure.

Our result also highlighted the challenge to measure DEHP in complex matrix. Indeed, we can observe that the lower the considered theoretical DEHP concentration, the higher is the difference between the theoretical and measured concentrations. After removing the basal contamination found in the controls (i.e. $392 \mathrm{ng} / \mathrm{g}$ ), we observed that the measured levels for the two lowest DEHP concentrations were 510 and 284 fold higher than theoretical, from 1.93 to 7.1 fold higher for the intermediate DEHP concentrations and closer to theoretical with the highest DEHP concentrations. We also noted that the SEM for the measured concentrations is increasing in the same manner for the lowest DEHP concentration suggesting that there is a higher variability of results when we are measuring the DEHP concentrations in the food with the lowest concentrations. These results are consistent with the report of comparative studies that highlighted that the current technics used for DEHP measurement have different selectivity/specificity, precision, sensitivity (evaluation of LOD and LOQ) as well as various problems of repeatability and matrix interference (Moldoveanu and Yerabolu, 2018). Moreover, matrix interference is usually one of the most important problems that researchers have to face when quantifying trace compounds of phthalates in complicated matrix samples (Snell, 1993; Ye et al, 2009). These interferences could lead to problem of DEHP detection or to differences between theoretical and measured concentrations. Even if these interferences do not call into question the results obtained on the development and the physiology of the insects, our results highlighted the need to quantify the atmospheric contamination but also the impact of matrix on DEHP measurement.

When fed with treated diet, larvae progressively accumulated DEHP, then the level of DEHP decreased during the last larval instars. This decrease was particularly spectacular for larvae fed with the higher dose $(4.3 \mathrm{mg} / \mathrm{g})$ and it continues until pupation, to reach DEHP levels that were closer to the levels observed for the other conditions. This decrease in DEHP content at the end of the larval stage may be explained by the developmental processes that are taking place during this time. Indeed, in order to prepare the pupal molt and metamorphosis, the larvae in the last days of the last instar (i.e. period of prepupae formation) are starting starvation, shrinking in size and purging their digestive system in order to eliminate the last metabolic wastes ( $\mathrm{Hu}$ et al. 2016). Moreover, we already highlighted the expression of several enzymes of detoxification in the larvae of S. littoralis (Durand et al. 2010; Pottier et al., 2012) suggesting abilities of this insect to detoxify xenobiotic compounds including DEHP.

A significant higher DEHP concentration in chrysalid and adults was observed for all treatments including control in comparison to larval concentration. This increase could be partly explained by the reduction of weight from last larval instar (average of $0.41 \mathrm{mg}$ of fresh weight per larvae) to chrysalid stage (average of $0.258 \mathrm{mg}$ and $0.264 \mathrm{mg}$ of fresh weight for males and females chrysalids respectively). The loss of weight after desiccation of insects for DEHP measurement is also a factor of difference. Thus, a 2.8-fold reduction of weight was observed in larvae whereas a 4.3 or 4.47 -fold reduction was observed in males and females chrysalids respectively. But these two factors of amplification could not explain alone the important increase of concentration and a passive atmospheric contamination during chrysalid stage could be considered. Chrysalis is an immobile stage, which has very low exchanges with the environment due to a high impermeability of cuticle. At the exception of gaseous exchanges (i.e. $\mathrm{O}_{2}$ and $\mathrm{CO}_{2}$ ), a chrysalis is living on its stock 
until adult emergence (Basson \& Terblanche, 2010). Thus, in comparison to larvae that can detoxify and eliminate DEHP, pupae do not have the possibility to perform such kind of physiological processes. Larvae of the Spodoptera gender have important detoxification abilities. Thus, two studies have compared the differences in the expression of detoxification genes during postembryonic development (Huang et al., 2011; Wand et al., 2015). They thus highlighted that a large number pf enzymes were expressed and often at high levels in larvae compared to other stages, allowing them to metabolize xenobiotic compounds and plant allelochemicals. This important expression of detoxification genes in Spodoptera larvae could also explain this important decrease of DEHP in our study. Adults seemed to be able to restart detoxification of DEHP as they present lower DEHP compared to chrysalises (Wilcoxon's test, $\mathrm{P}<0.05$ ). Interestingly, this phenomenon is not general since we observed a difference in the concentration between males and females for similar DEHP conditions. This result showed that there is probably a difference in the detoxification processes between the two sexes. Even if there is to date no evidence of gender difference in detoxification of DEHP in insects, several articles already highlighted it for other pollutants (Occai et al., 2018).

431

432

433

434

435

436

437

438

439

440

441

442

443

444

445

446

447

448

449

450

451

452

453

454

455

456

457

458

459

460

461

462

463

464

465

466

467

\section{Effect of DEHP on post-embryonic development}

We observed in this study for the first time the effects of DEHP ingestion on the postembryonic development of a terrestrial insect. We highlighted by this study different disruptive effects of DEHP on S. littoralis. However, DEHP is known to rapidly degrade to MEHP and this metabolite is also known to induce various toxic effects in exposed organisms (Kalo \& Roth, 2017). Thus, although we did not measure MEHP concentrations in this study, it is highly likely that the observed disturbances are due to DEHP and MEHP.

The two highest non-environmentally relevant concentrations tested here increased significantly the mortality of larvae and pupae, whereas the other doses were not lethal. The highest DEHP dose also induced a reduction of larval growth. This decrease may partially result from the reduction of larval food consumption and/or from a toxic effect of DEHP on metabolism. In a recent work, Cuvilliers-Hot et al. (2014) demonstrated that workers of the Lasius niger ant can detect and avoid food contaminated by environmentally-relevant doses of DEHP. However, this behavior was not observed for S. littoralis larvae fed on all the other DEHP conditions as their food consumption was on contrary increased, while their body mass remained similar to that of control larvae. In vertebrates, several deleterious effects of DEHP have been reported, on gut or digestive glands, with induction of tumors (Chen et al. 2017), genotoxicity (Kitamoto et al., 2015), disruption of cholesterol homeostasis, deregulation of the inflammatory response, and acceleration of atherosclerosis (Zhao et al. 2016). As a result, DEHP may have induced digestive problems to $S$. littoralis larvae such as malabsorption or altered digestion, which could have been compensated by increased food intake. This increase could be also explained by the DEHP detoxification leading to an increase of energetic needs in exposed insects. On the contrary, exposure to environmental doses of DEHP led to an increase of female body mass in Chironomus riparius, and to increased larval body mass in Chironomus tentans (Kwak \& Lee, 2005; Lee et al., 2006).

DEHP treatments also altered the duration of the life cycle. Longer larval or pupal stages were observed for intermediate (i.e. $19.7 \mu \mathrm{g}$ and $442 \mu \mathrm{g}$ ) and high DEHP concentrations (i.e. 4.3 $\mathrm{mg}$ and $19.5 \mathrm{mg} / \mathrm{g}$ ) leading globally to a delay in adult emergence after exposure to concentrations higher than $1.1 \mu \mathrm{g} / \mathrm{g}$ of DEHP. In crustaceans, several studies have shown that exposure to DEHP disrupts the timing of development and molting without induction of mortality (Zou and Fingerman, 1997; Billinghurst et al., 2001; Marcial et al., 2003). For instance, the survival of the estuarine copepod Eurytemora affinis (nauplius stage) was unaffected after ten days of DEHP exposure, but the animals remained in the nauplius stage, or reached the copepodid stage later than controls (Forget-Leray et al., 2005). However, in the marine copepod Calanus helgolandicus a prolonged exposure (i.e. nine days) to DEHP did not decrease survival (Cole et al., 2015) and similarly, in the springtail Folsomia fimetaria (Jensen et al., 2001), DEHP treatment had no effect on survival, reproduction, growth, or molting of juveniles. However, there are some exceptions, with for 
example the high sensitivity of the copepod Parvocalanus crassirostris nauplii to DEHP, with significantly higher mortality rates after $48 \mathrm{~h}$ as compared to control, even at very low environmental concentrations (Heindler et al., 2017).

The developmental events that take place during the last larval stage depend on the peak of 20E. Our results highlight that the peak of $20 \mathrm{E}$ in S. littoralis is at day 6. Following the peak, a decrease of the $20 \mathrm{E}$ concentration should be observed, as well as the induction of molecular signaling pathways including nuclear receptor expression in various targeted tissues. All these events trigger the prepupal and pupal molts. Any disruption of these processes could lead to developmental disturbances, as we were able to see in our study. Significant changes in ecdysteroid concentrations were indeed observed in L7 larvae fed on DEHP-enriched diet at day 7, in parallel to modifications of the expression levels of several nuclear receptors (i.e. EcRB, USP and E75D) during this last instar. We observed a decrease of $E c R B$ expression at day 6 in larvae exposed to 4.3 $\mathrm{mg} / \mathrm{g}$ of DEHP and of USP gene expression during three days (5 to 7) in larvae exposed to $19.7 \mu \mathrm{g}$ and $4.3 \mathrm{mg} / \mathrm{g}$ of DEHP. This finding, consistent with the study of Herrero et al. (2017), suggests that DEHP could function as an ecdysone antagonist. Even if feedback regulations of the early and early-late genes on their own expression and on the expressions of EcR and USP can take place in the ecdysteroid pathways (Ashburner, 1974; Huet et al., 1995), DEHP appeared to induce a downregulation of $E c R$ and $U S P$ genes in larvae of $S$. littoralis fed with $19.7 \mu \mathrm{g}$ and $4.3 \mathrm{mg} / \mathrm{g}$ of DEHP. On the contrary, at day $7 E 75 D$ expression appeared to be increased at high dose but also significantly reduced at lower dose $(1.1 \mu \mathrm{g}$ DEHP/g), showing that DEHP can differently disrupt endocrine pathway depending on the dose.

At the $7^{\text {th }}$ day, L7 larvae exposed to $4.3 \mathrm{mg} / \mathrm{g}$ DEHP had a higher hemolymphatic concentration of ecdysteroids and a higher level of E75D expression than the controls; whereas the larvae exposed to the lowest dose (i.e. $1.1 \mu \mathrm{g} / \mathrm{g}$ ) had a lower level of circulating hormone and of E75D expression. In vertebrates, several studies highlighted that DEHP, can probably modulate the level of circulating hormones by disrupting the activity of enzymes involved in the synthesis of endogenous steroids and their metabolism (Thibaut \& Porte, 2004). Even if down- and upregulations are usually taking place in the ecdysteroid signaling pathway, an increase of circulating ecdysteroids generally induced an increase of nuclear receptor expression (Bigot et al., 2012; Jing et al., 2016). Moreover, the chemical structure of DEHP, close to other endocrine disruptors as DiethylPhthalate (DEP), may probably permit its binding to ecdysteroid receptors and disrupt activation of the nuclear signaling pathway (Dinan et al., 2001). Our results showed both the effect of DEHP exposure on hemolymphatic ecdysteroid concentrations and expression level of nuclear receptors, bringing out the endocrine disruption nature of DEHP in S. littoralis. These variations may contribute in the modification of the duration of the larval and pupal stages observed for some DEHP treatments.

We also noted a significant imbalance in the male versus female ratio, showing a slight feminization of the population for one treatment. If modification of sex ratio by DEHP was already reported in vertebrates (Tanaka, 2003; Xi et al., 2011; Hou et al., 2015), there are very few studies on its effect (or of other plastic products) on the sex ratio in arthropods. Kim and Lee (2004) observed a modification of hatching rates of F1 egg ropes from DEHP exposed adult C. riparius, without effects on sex-ratio. In particular, Forget-Leray et al. (2005) highlighted a feminization of the copepod E. affinis after an exposure to a mix of estradiol and DEHP. Conversely, bisphenol A (BPA) induced a feminization in C. riparius (Lee \& Choi, 2007). It is generally accepted that sex determinism in insects is predominantly genetic, and numerous studies showed the importance of gene expression or epigenetic regulation in sex determination (Kan et al., 2017; Mine et al., 2017). Thus, the sex ratio disruption in $S$. littoralis may more probably result from an endocrine disruption of these processes rather than to hemolymphatic ecdysteroid variations.

The metabolomic profiling performed here highlighted a progressive change of the metabolic phenotype during the last larval instar of S. littoralis. This transition may have mirrored hemolymphatic changes of ecdysteroid concentrations, which peak induces the next molt and the transition to the pupa, which has a quite different metabolism than larvae. The rising concentrations 
of a large number of metabolites from the 5 th to the 7 th day reflected the increased activity of the pentose phosphate pathway, the fatty acids biosynthesis, gluconeogenesis, glycolysis, TCA cycle and amino acids' pathways. The general increase in biosynthesis activity may prepare larvae to the pupal stage, during which insect has high energetic requirements linked to metamorphosis. At the $6^{\text {th }}$ and $7^{\text {th }}$ day, for the doses of $1.1 \mu \mathrm{g}$ and $19.7 \mu \mathrm{g}$ of DEHP, we observed a decrease in the concentrations of several metabolites mainly involved in energetic production and amino acids production. It is likely that the energetic costs of DEHP/MEHP detoxification and elimination could impact the metabolic activities of the prepupae. We should also consider that DEHP/MEHP can have a direct inhibitory effect on enzyme activity or expression as already demonstrated in the literature (Wang et al., 2018).

More generally, there also seems to be a shunt in the energetic metabolism since the decrease of several metabolites (i.e. alanine, serine, threonine, leucine, phenylalanine) coupled to a decrease of the TCA cycle (i.e. citrate, fumarate, malate, succinate) seems to benefit the production of glucose through gluconeogenesis. This decrease of metabolites involved in various energetic pathways could be potentially the expression of this negative biological cost of DEHP on developmental processes. Our results are consistent with the negative effect of DEHP on energetic production and more particularly on TCA cycle already reported in vertebrates (Chiang et al., 2016). At the highest dose of DEHP (i.e. $4.3 \mathrm{mg} / \mathrm{g}$ ), the stress seemed to be very important (i.e. mortality induction for some individuals) and no significant effect was observed on metabolites' concentrations at the exception of the lower quantity of lactic acid indicating a probable reduction of the gluconeogenesis process and an increase of trehalose, which is involved generally in cellular protection. Levels of trehalose, the prominent 'blood sugar' in most insect species (Thomson, $\underline{2003}$ ), have already been found to increase in Bombyx mori and S. litura following exposure to sublethal doses of various pesticides (Nath, 2003; Etebari et al., 2007; Zhu et al., 2012, Dewer et al., $\underline{2015}$ ), suggesting that this sugar serves a protective role for proteins and cellular membranes from inactivation and/or denaturation (Elbein et al., 2003).

\section{Conclusion}

We showed here that DEHP acts as an endocrine disruptor in S. littoralis, by inducing variations in ecdysteroid and nuclear receptor levels. However, the effects were dependent on DEHP doses. The highest concentrations, currently not observed in the environment, had stressful consequences, by inducing mortality, physiological and growth problems. The intermediate doses, found in environment, did not induce marked effects on S. littoralis. Further investigations have to be done in order to study the abilities of larvae to detoxify or eliminate DEHP. The disruption of metabolite quantities could potentially be linked to the increase of the pupal period duration since not enough metabolites were stocked before this stage. Considering all these results, it would be very interesting to study the effect of DEHP on later processes such as reproduction and cross generational effects.

Funding: This work was supported by the French National Research Agency (ANR) [project endocrine Disruption of Insect Sexual Communication 2016-2019] and grant for INRA SPE department

\section{References}

1. Andrady AL \& Neal MA (2009). Applications and societal benefits of plastics. Phil. Trans. R. Soc. B 364, 1977-1984.

2. Ashburner, M., 1974. Sequential gene activation by ecdysone in polytene chromosomes of Drosophila melanogaster. II. The effects of inhibitors of protein synthesis. Dev. Biol. 39, 141-157.

3. Bar-El DS and Reifen R (2010). Soy as an endocrine disruptor: cause for caution? J Pediatric Endocrino Metabo 23: 855-861.

4. Basson CH, Terblanche JS. Metabolic responses of Glossina pallidipes (Diptera: Glossinidae) puparia exposed to oxygen and temperature variation: implications for population dynamics and subterranean life. J Insect Physiol. 2010 Dec;56(12):1789-97. doi: 10.1016/j.jinsphys.2010.07.010. Epub 2010 Aug 1. 

leaching from household wastes. Sci. Total Environ. 208, 49-57.

6. Bergé, A., Cladière, M., Gasperi, J., Coursimault, A., Tassin, B., Moilleron, R., 2013. Meta-analysis of environmental contamination by phthalates. Environ. Sci. Pollut. Res. 20, 8057-8076. doi:10.1007/s11356013-1982-5

7. Bigot, L., Shaik, H.A., Bozzolan, F., Party, V., Lucas, P., Debernard, S., Siaussat, D., 2012. Peripheral regulation by ecdysteroids of olfactory responsiveness in male Egyptian cotton leaf worms, Spodoptera littoralis. Insect Biochem. Mol. Biol. 42, 22-31.

8. Billinghurst Z, Clare AS, Depledge MH. 2001. Effects of 4-n-nonylphenol and 17beta-oestradiol on early development of the barnacle Elminius modestus. J Exp Mar Bio Ecol. 2001 Mar 15;257(2):255-268.

9. Casals-Casas C and Desvergne B (2011). Endocrine Disruptors: From Endocrine to Metabolic Disruption.Annu Rev Physiol 73: 135-162.

10. Chen HP, Pan MH, Chou YY, Sung C, Lee KH, Leung CM, Hsu PC. Effects of di(2-ethylhexyl)phthalate exposure on 1,2-dimethyhydrazine-induced colon tumor promotion in rats. Food Chem Toxicol. 2017 May;103:157-167.

11. Chiang HC, Kuo YT, Shen CC, Lin YH, Wang SL, Tsou TC. Mono(2-ethylhexyl)phthalate accumulation disturbs energy metabolism of fat cells. Arch Toxicol. 2016 Mar;90(3):589-601. doi: 10.1007/s00204-0141446-9.

12. Cole M, Lindeque P, Fileman E, Halsband C, Galloway TS. 2015 The impact of polystyrene microplastics on feeding, function and fecundity in the marine copepod Calanus helgolandicus. Environ Sci Technol. 49(2):1130-7.

13. Cuvillier-Hot V, Salin K, Devers S, Tasiemski A, Schaffner P, Boulay R, Billiard S, Lenoir A. 2014 Impact of ecological doses of the most widespread phthalate on a terrestrial species, the ant Lasius niger. Environ Res. 131:104-10.

14. deFur PL, Crane M, Ingersoll CG, Tatterfield L (1999). Endocrine disruption in invertebrates: Endocrinology testing and assessment. SETAC techn pub, Pensacola, Florida, pp303.

15. Dewer Y, Pottier MA, Lalouette L, Maria A, Dacher M, Belzunces LP, Kairo G, Renault D, Maibeche M, Siaussat D. 2016 Behavioral and metabolic effects of sublethal doses of two insecticides, chlorpyrifos and methomyl, in the Egyptian cotton leafworm, Spodoptera littoralis (Boisduval) (Lepidoptera: Noctuidae). Environ Sci Pollut Res Int. 23(4):3086-96.

16. Dinan L, Bourne P, Whiting P, Dhadialla TS, Hutchinson TH. (2001). Screening of environmental contaminants for ecdysteroid agonist and antagonist activity using the Drosophila melanogaster B(II) cell in vitro assay. Environ Toxicol Chem. $2001 \mathrm{Sep} ; 20(9): 2038-46$.

17. Du Q, Shen L, Xiu L, Jerz G, Winterhalter P. (2006) . Di-2-ethylhexyl phthalate in the fruits of Benincasa hispida. Food Addit Contam. 23(6):552-5.

18. Du QZ, Wang JW, Fu XW, Xia HL. (2010). Diffusion and accumulation in cultivated vegetable plants of di(2-ethylhexyl) phthalate (DEHP) from a plastic production factory. Food Addit Contam Part A Chem Anal Control Expo Risk Assess. 27(8):1186-92.

19. Durand N, Carot-Sans G, Chertemps T, Montagné N, Jacquin-Joly E, Debernard S, Maïbèche-Coisne M. A diversity of putative carboxylesterases are expressed in the antennae of the noctuid moth Spodoptera littoralis. Insect Mol Biol. 2010 Feb;19(1):87-97.

20. Elbein, AD, Pan, YT, Pastuszak, I, Carroll, D (2003). New insights on trehalose: a multifunctional molecule. Glycobiology 13(4):17-27

21. Etebari K, Bizhannia AR, Sorati R, Matindoost L (2007). Biochemical changes in hemolymph of silkworm larval due to pyriproxyfen residue. Pesticide Biochemistry and Physiology 88:14-19.

22. EU, 2008. European Union Risk Assessment Report: Bis(2-ethylhexyl)phthalate (DEHP). Eur. Comm. - Jt. Res. Centre. Luxemb. 80, 588.

23. Forget-Leray J, Landriau I, Minier C, Leboulenger F. Impact of endocrine toxicants on survival, development, and reproduction of the estuarine copepod Eurytemora affinis (Poppe). Ecotoxicol Environ Saf. 2005 Mar;60(3):288-94.

24. Fromme H, Kuchler T, Otto T, Muller T (2002). Occurrence of phthalates and bisphenol A and $\mathrm{F}$ in the environment. Water Res 36: 1429-1438.

25. Fu X, Du Q. (2011). Uptake of di-(2-ethylhexyl) phthalate of vegetables from plastic film greenhouses. J Agric Food Chem. 59(21):11585-8.

26. Guehlstorf NP (2004). The political theories of risk analysis. Springer

27. Hanioka N, Naito T, Narimatsu S (2008). Human UDP-glucuronosyltransferase isoforms involved in bisphenol A glucuronidation. Chemosphere 74: 33-36.

28. He L, Fan S, Müller K, Hu G, Huang H, Zhang X, Lin X, Che L, Wang H. (2016). Biochar reduces the bioavailability of di-(2-ethylhexyl) phthalate in soil. Chemosphere. 142:24-7.

29. Heindler FM, Alajmi F, Huerlimann R, Zeng C, Newman SJ, Vamvounis G, van Herwerden L. Toxic effects of polyethylene terephthalate microparticles and $\mathrm{Di}(2$-ethylhexyl)phthalate on the calanoid copepod, Parvocalanus crassirostris. Ecotoxicol Environ Saf. 2017 Jul;141:298-305. 
30. Herrero, Ó., Morcillo, G., Planelló, 2017. Transcriptional deregulation of genetic biomarkers in Chironomus riparius larvae exposed to ecologically relevant concentrations of di(2-ethylhexyl) phthalate (DEHP). PLoS One 12, e0171719.

31. Hinks, C.F. and Byers, J.R., 1976. Biosystematics of the genus euxoa (lepidoptera: noctuidae): V. rearing procedures, and life cycles of 36 species. The Canadian Entomologist. 108(12), 1345-1357.

32. Hou JW, Lin CL, Tsai YA, Chang CH, Liao KW, Yu CJ, Yang W, Lee MJ, Huang PC, Sun CW, Wang YH, Lin FR, Wu WC, Lee MC, Pan WH, Chen BH, Wu MT, Chen CC, Wang SL, Lee CC, Hsiung CA, Chen ML. The effects of phthalate and nonylphenol exposure on body size and secondary sexual characteristics during puberty. Int J Hyg Environ Health. 2015 Oct;218(7):603-15.

33. Huang Y, Xu Z, Lin X, Feng Q, Zheng S. Structure and expression of glutathione S-transferase genes from the midgut of the Common cutworm, Spodoptera litura (Noctuidae) and their response to xenobiotic compounds and bacteria. J Insect Physiol. 57(7):1033-44.

34. Hu D, Luo W, Fan LF, Liu FL, Gu J, Deng HM, Zhang C, Huang LH, Feng QL. Dynamics and regulation of glycolysis-tricarboxylic acid metabolism in the midgut of Spodoptera litura during metamorphosis. Insect Mol Biol. 2016 Apr;25(2):153-62. doi: 10.1111/imb.12208. Epub 2015 Dec 19.

35. Huet, F., Ruiz, C., Richards, G., 1995. Sequential gene activation by ecdysone in Drosophila melanogaster: the hierarchical equivalence of early and early late genes. Development 121, 1195-1204.

36. Jensen J1, van Langevelde J, Pritzl G, Krogh PH. Effects of di(2-ethylhexyl) phthalate and dibutyl phthalate on the collembolan Folsomia fimetaria. Environ Toxicol Chem. 2001 May;20(5):1085-91.

37. Jing YP, Wang D, Han XL, Dong DJ, Wang JX, Zhao XF. The Steroid Hormone 20-Hydroxyecdysone Enhances Gene Transcription through the cAMP Response Element-binding Protein (CREB) Signaling Pathway. J Biol Chem. 2016 Jun 10;291(24):12771-85.

38. Jordan J, Zare A, Jackson LJ, Habibi HR, Weljie AM (2012). Environmental contaminant mixtures at

39. ambient concentrations invoke a metabolic stress response in goldfish not predicted from exposure to individual compounds alone. J Proteome Res. 11(2):1133-43.

40. Kalo D, Roth Z. (2017). ow level of mono(2-ethylhexyl) phthalate reduces oocyte developmental competence in association with impaired gene expression. Toxicology 15;377:38-48.

41. Kan L, Grozhik AV, Vedanayagam J, Patil DP, Pang N, Lim KS, Huang YC, Joseph B, Lin CJ, Despic V, Guo J, Yan D, Kondo S, Deng WM, Dedon PC, Jaffrey SR, Lai EC. The m6A pathway facilitates sex determination in Drosophila. Nat Commun. 2017 Jul 4;8:15737.

42. Kim EJ, Lee SK. Reduced viability of F1 egg ropes in Chironomus riparius exposed to di-2-ethylhexyl phthalate (DEHP). J Environ Biol. 2004 Jul;25(3):259-61.

43. Kitamoto S, Matsuyama R, Uematsu Y, Ogata K, Ota M, Yamada T, Miyata K, Kimura J, Funabashi H, Saito K. Genotoxicity evaluation of benzene, di(2-ethylhexyl) phthalate, and trisodium ethylenediamine tetraacetic acid monohydrate using a combined rat comet/micronucleus assays. Mutat Res Genet Toxicol Environ Mutagen. 2015 Jul;786-788:137-43.

44. Khodayari S, Moharramipour S, Larvor V, Hidalgo K, Renault D. Deciphering the metabolic changes associated with diapause syndrome and cold acclimation in the two-spotted spider mite Tetranychus urticae. PLoS One. 2013;8(1):e54025. doi: 10.1371/journal.pone.0054025. Epub 2013 Jan 17. Erratum in: PLoS One. $2013 ; 8(3)$.

45. Kwak, I.S., Lee, W., 2005. Endpoint for DEHP exposure assessment in Chironomus riparius. Bull. Environ. Contam. Toxicol. 74, 1179-1185.

46. Lee SM, Lee SB, Park CH, Choi J. 2006 Expression of heat shock protein and hemoglobin genes in Chironomus tentans (Diptera, chironomidae) larvae exposed to various environmental pollutants: a potential biomarker of freshwater monitoring. Chemosphere 65(6):1074-81.

47. Lee SB1, Choi J. 2007. Effects of bisphenol A and ethynyl estradiol exposure on enzyme activities, growth and development in the fourth instar larvae of Chironomus riparius (Diptera, Chironomidae). Ecotoxicol Environ Saf. 68(1):84-90.

48. Lenoir A, Cuvillier-Hot V, Devers S, Christidès J-P, Montigny F (2012) Ant cuticles: a trap for atmospheric phthalate contaminants. Sci Total Environ 441:209 - 212

49. Magdouli, S., Daghrir, R., Brar, S.K., Drogui, P., Tyagi, R.D., 2013. Di 2-ethylhexylphtalate in the aquatic and terrestrial environment: A critical review. J. Environ. Manage. 127, 36-49.

50. Marcial HS, Hagiwara A, Snell TW. 2003. Estrogenic compounds affect development of harpacticoid copepod Tigriopus japonicus. Environ Toxicol Chem. 22(12):3025-30.

51. Matthiessen P, Wheeler JR, Weltje L. A review of the evidence for endocrine disrupting effects of current-use chemicals on wildlife populations. Crit Rev Toxicol. 2018 Mar;48(3):195-216. doi: 10.1080/10408444.2017.1397099. Epub 2017 Nov 24.

52. Mine S, Sumitani M, Aoki F, Hatakeyama M, Suzuki MG. Identification and functional characterization of the sex-determining gene doublesex in the sawfly, Athalia rosae (Hymenoptera: Tenthredinidae) Appl. Entomol. Zool. (Jpn.). 2017;52(3):497-509.

53. Moldoveanu SC, Yerabolu R (2018). Critical evaluation of several techniques for the analysis of phthalates and terephthalates: Application to liquids used in 
54. Nath BS (2003). Shifts in glycogen metabolism in hemolymph and fat body of the silkworm. Pesticide Biochemistry and Physiology 74(2):73-84.

55. Occai BK, Hassan W, da Rocha JBT. Gender-based behavioral and biochemical effects of diphenyl diselenide in Drosophila melanogaster. Chem Biol Interact. 2018 Jan 5;279:196-202. doi: 10.1016/j.cbi.2017.10.027. Epub 2017 Dec 11.

56. Oehlmann J and Schulte-Oehlmann U (2003). Endocrine disruption in invertebrates. Pure Applied Chem 75 : 2207-2218.

57. Pfaffl MW, Tichopad A, Prgomet C, Neuvians TP. Determination of stable housekeeping genes, differentially regulated target genes and sample integrity: BestKeeper--Excel-based tool using pair-wise correlations. Biotechnol Lett. 2004 Mar;26(6):509-15.

58. Planelló, R., Herrero, O., Martínez-Guitarte, J.L., Morcillo, G., 2011. Comparative effects of butyl benzyl phthalate (BBP) and di(2-ethylhexyl) phthalate (DEHP) on the aquatic larvae of Chironomus riparius based on gene expression assays related to the endocrine system, the stress response and ribosomes. Aquat. Toxicol. $105,62-70$.

59. Porcheron, P., Moriniere, M., Grassi, J., Pradelles, P., 1989. Development of an enzyme immunoassay for ecdysteroids using acetylcholinesterase as label. Insect Biochem. 19(2), 117-122.

60. Porter CM and Janz DM (2003). Treated municipal sewage discharge affects multiple levels of biological organization in fish. Ecotoxico Environ Safety 54: 199-206.

61. Posnack NG, Swift LM, Kay MW, Lee NH, Sarvazyan N (2012). Phthalate exposure changes the metabolic profile of cardiac muscle cells. Environ Health Perspect. 120(9):1243-1251.

62. Pottier MA, Bozzolan F, Chertemps T, Jacquin-Joly E, Lalouette L, Siaussat D, Maïbèche-Coisne M. Cytochrome P450s and cytochrome P450 reductase in the olfactory organ of the cotton leafworm Spodoptera littoralis. Insect Mol Biol. 2012 Dec;21(6):568-80.

63. Ran, D., Cai, S., Wu, H., Gu, H., 2012. Di (2-ethylhexyl) phthalate modulates cholinergic mini-presynaptic transmission of projection neurons in Drosophila antennal lobe. Food Chem. Toxicol. 50, 3291-3297.

64. Siaussat D, Bozzolan F, Porcheron P, Debernard S. 2008. The 20-hydroxyecdysone-induced signalling pathway in G2/M arrest of Plodia interpunctella imaginal wing cells. Insect Biochem Mol Biol. 38(5):529-39.

65. Simon, P., 2003. Q-Gene: Processing quantitative real-time RT-PCR data. Bioinformatics 19, 1439-1440.

66. Snell RP (1993). Solid-phase extraction and liquid chromatographic determination of monophthalates and phthalide extracted from solution administration sets. J AOAC Int. $76(3): 531-4$.

67. Staples CA, Woodburn K, Caspers N, Hall AT \& Klecka GM (2002). A weight of evidence approach to the aquatic hazard assessment of bisphenol A. Hum. Ecol. Risk Assess. 8, 1083-1105.

68. Stoker C, Beldomenico PM, Bosquiazzo VL, Zayas MA, Rey F, Rodriguez H, Munoz M, Luque EH (2008). Developmental exposure to endocrine disruptor chemicals alters follicular dynamics and steroid levels in C. latirostris. Gen Comp Endoc 156: 603-612.

69. Sun, J., Wu, X., Gan, J., 2015. Uptake and Metabolism of Phthalate Esters by Edible Plants. Environ. Sci. Technol. 49, 8471-8.

70. Tanaka T. Effects of bis(2-ethylhexyl) phthalate (DEHP) on secondary sex ratio of mice in a cross-mating study. Food Chem Toxicol. 2003 Oct;41(10):1429-32.

71. Tarrant AM, Behrendt L, Stegeman JJ, Verslycke T (2011). Ecdysteroid receptor from the American lobster $H$. americanus: EcR/RXR isoform cloning and ligand-binding properties. General Comp Endocrino 173: 346355 .

72. Thibaut R, Porte C. 2004 Effects of endocrine disrupters on sex steroid synthesis and metabolism pathways in fish.

J Steroid Biochem Mol Biol. 92(5):485-94. Epub 2004 Dec 21.

73. Thompson SN (2003). Trehalose-the insect 'blood' sugar. Adv Insect Physiol 31:205-285.

74. Uren-Webster, T.M., Lewis, C., Filby, A.L., Paull, G.C., Santos, E.M., 2010. Mechanisms of toxicity of di(2ethylhexyl) phthalate on the reproductive health of male zebrafish. Aquat. Toxicol. 99, 360-369.

75. Vandenberg, L.N., Colborn, T., Hayes, T.B., Heindel, J.J., Jacobs, D.R., Lee, D.H., Shioda, T., Soto, A.M., vom Saal, F.S., Welshons, W. V., Zoeller, R.T., Myers, J.P., 2012. Hormones and endocrine-disrupting chemicals: Low-dose effects and nonmonotonic dose responses. Endocr. Rev. 33, 378-455.

76. Wang B, Wan X, Zhao SM, Wang Y, Yu F, Pan XJ (2011). Analysis of Six Phenolic endocrine Disrupting Chemicals in Surface Water and Sediment. Chromato 74: 297-306.

77. Wang H, Liang H, Gao DW. 2017. Occurrence and risk assessment of phthalate esters (PAEs) in agricultural soils of the Sanjiang Plain, northeast China. Environ Sci Pollut Res Int. 24(24):19723-19732.

78. Wang Y, Wang T, Ban Y, Shen C, Shen Q, Chai X, Zhao W, Wei J. (2018). Di-(2-ethylhexyl) Phthalate Exposure Modulates Antioxidant Enzyme Activity and Gene Expression in Juvenile and Adult Daphnia magna. Arch Environ Contam Toxicol. 75(1):145-156. 
79. Wang RL, Li J, Staehelin C, Xin XW, Su YJ, Zeng RS (2015). Expression analysis of two P450 monooxygenase genes of the tobacco cutworm moth (Spodoptera litura) at different developmental stages and in response to plant allelochemicals. J Chem Ecol. 41(1):111-9.

80. Wetherill YB, Akingbemi BT, Kannod J, McLachlan JA, Nadal A, Sonnenschein C, Watson CS, Zoeller RT, Belcher SM (2007), In vitro molecular mechanisms of bisphenol A action. Reprod Toxico 24: 178-198.

81. Wofford HW, Wilsey CD, Neff GS, et al. (1981). Bioaccumulation and metabolism of phthalate esters by oysters, brown shrimp, and sheepshead minnows. Ecotoxicol Environ Safety 5:202-210.

82. Wu Z, Zhang X, Wu X, Shen G, Du Q, Mo C. (2013) Uptake of di(2-ethylhexyl) phthalate (DEHP) by the plant Benincasa hispida and its use for lowering DEHP content of intercropped vegetables. J Agric Food Chem. 61(22):5220-5.

83. Xi W, Wan HT, Zhao YG, Wong MH, Giesy JP, Wong CK. Effects of perinatal exposure to bisphenol A and di(2-ethylhexyl)-phthalate on gonadal development of male mice. Environ Sci Pollut Res Int. 2011 Aug;19(7):2515-27.

84. Ye, T., Kang, M., Huang, Q., Fang, C., Chen, Y., Shen, H., Dong, S., 2014. Exposure to DEHP and MEHP from hatching to adulthood causes reproductive dysfunction and endocrine disruption in marine medaka (Oryzias melastigma). Aquat. Toxicol. 146, 115-126.

85. Ye CW, Gao J, Yang C, Liu XJ, Li XJ, Pan SY. (2009). Development and application of an SPME/GC method for the determination of trace phthalates in beer using a calix[6]arene fiber. 641(1-2):64-74. doi: 10.1016/j.aca.2009.02.052.

86. Zeng, F., Cui, K., Xie, Z., Liu, M., Li, Y., Lin, Y., Zeng, Z., Li, F., 2008. Occurrence of phthalate esters in water and sediment of urban lakes in a subtropical city, Guangzhou, South China. Environ. Int. 34, 372-380.

87. Zhao HM, Du H, Xiang L, Chen YL, Lu LA, Li YW, Li H, Cai QY, Mo CH.Variations in phthalate ester (PAE) accumulation and their formation mechanism in Chinese flowering cabbage (Brassica parachinensis L.) cultivars grown on PAE-contaminated soils. Environ Pollut. 206:95-103.

88. Zhao JF, Hsiao SH, Hsu MH, Pao KC, Kou YR, Shyue SK, Lee TS. Di-(2-ethylhexyl) phthalate accelerates atherosclerosis in apolipoprotein E-deficient mice. Arch Toxicol. 2016 Jan;90(1):181-90.

89. Zhang BC (1994). Index of economically important Lepidoptera. CAB International, Wallingford, UK

90. Zou E, Fingerman M. 1997. Effects of estrogenic xenobiotics on molting of the water flea, Daphnia magna. Ecotoxicol Environ Saf. 1997 Dec;38(3):281-5.

91. Zhu F et al. (2012). RNA interference of NADPH-Cytochrome P450 reductase results in reduced insecticide resistance in the Bed Bug, Cimex lectularius. PLos ONE 7(2):e31037.

\section{Legends}

Figure 1. DEHP concentrations in control and contaminated diet (in ng of DEHP per gram of fresh food). (A) Quantity of DEHP measured in control and contaminated diet in ng per g of food (fresh weight). Each bar represents the mean of values with representation of SEM ( $n=6$ to 11 for each condition). (B) Correspondence between theoretical and measured ${ }^{(*)}$ or estimated $^{(\mathrm{e})}$ concentrations in contaminated diet. Asterisks indicate significant differences among means in comparison to controls $(* \mathrm{P}<0.05 ; * * \mathrm{P}<0.01 ; * * * \mathrm{P}<0.001)$.

Figure 2. DEHP concentrations during development of S. littoralis. Concentrations in ng of DEHP per gram of fresh weight found in larval stages (i.e. L5, L6 or L7), in males and females during the pupal and adult stages ( $n=3-4$ biological replicates for each condition corresponding to a pool of 3 to 10 individuals). For each condition and stage, the mean value \pm SEM was indicated. For statistical analysis, significant difference is indicated by a different letter. The first uppercase letter, $\mathrm{X}$ in $(\mathrm{X} / \mathrm{y})$, is for the statistical comparison by focusing on one specific stage between the different DEHP conditions (i.e. control, $1.1 \mu \mathrm{g}, 19.7 \mu \mathrm{g}$ and $4.3 \mathrm{mg} / \mathrm{g}$ ). The second lowercase letter, $\mathrm{y}$ in $(\mathrm{X} / \mathrm{y})$, is for the statistical comparison made for a similar DEHP (or control) condition between only L5, L6, L7 stages or between only male $\left(\mathrm{C}^{\hat{O}}\right)$ and female (C $\bigcirc$ ) chrysalises, or finally between only adult males $(\hat{0})$ and females $(Q)$.

Figure 3. Effect of DEHP on the mortality of larval and pupal stages. Cumulated percentages of mortality were compared between larvae treated with DEHP and control larvae $(n=35$ for each conditions). Asterisks indicate significant differences among means in comparison to controls (* $\mathrm{P}<0.05 ; * * \mathrm{P}<0.01 ; * * * \mathrm{P}<0.001)$. 
Figure 4. Effect of DEHP on post-embryonic development time. The durations (in days) of larval (i.e. L4, L5, L6, and L7) and pupal stages observed for DEHP-contaminated larvae were compared to the control conditions ( $\mathrm{n}=35$ for each conditions). The complete development time from L4 up to adult emergence is also represented ("Total"). Different letters indicate a significant difference between controls and treated individuals of a same stage.

Figure 5. Effect of DEHP on the sex ratio repartition at pupal stage. The percentages of male and female pupae obtained from larvae treated with DEHP by food ingestion (from $1.1 \mu \mathrm{g} / \mathrm{g}$ to $19.5 \mathrm{mg} / \mathrm{g})$ were compared to the percentage of controls $(\mathrm{n}=72$ to 100$)$. Asterisks indicate significant differences among means in comparison to controls $(* \mathrm{P}<0.05$; ** $\mathrm{P}<0.01$; *** $\mathrm{P}<0.001)$.

Figure 6. Effect of DEHP on larval weight (A) and food consumption (B) after continuous ingestion of food contaminated with various concentrations of DEHP. Weights of larvae and food were measured at each molt for L4, L5 and L6 and daily during the last larval instar (L7). Each point represents the mean value ( $\mathrm{n}=35$ for each conditions). The bar under the horizontal axis indicates the corresponding larval instar. Asterisks indicate significant differences among means in comparison to controls $(* \mathrm{P}<0.05 ; * * \mathrm{P}<0.01$; *** $\mathrm{P}<0.001)$.

Figure 7. Quantification of hemolymphatic concentration of ecdysteroid (in fmol $20 \mathrm{E}$ eq/ $\mu \mathrm{L}$ ) in contaminated or control larvae at the $5^{\text {th }}, 6^{\text {th }}$ and $7^{\text {th }}$ day of the last larval instar ( $n=7$ to 12 ). Ecdysteroid concentrations were quantified by EIA. Bars with asterisks indicate significant differences among means in comparison to controls (* $\mathrm{P}<0.05$; ** $\mathrm{P}<0.01$; *** $\mathrm{P}<0.001$ ).

Figure 8. Normalized expression of nuclear receptor (EcRB, USP, E75D, E75A/B) in contaminated or control larvae at the $5^{\text {th }}, 6^{\text {th }}$ and $7^{\text {th }}$ day of the last larval instar $(\mathrm{n}=6$ for each condition). Expression levels were quantified by quantitative PCR. Bars with asterisks indicate significant differences among means in comparison to controls $(* \mathrm{P}<0.05$; ** $\mathrm{P}<0.01$; *** $\mathrm{P}<0.001)$.

Figure 9. Schematic representation of the metabolic pathways in the last instar of control larvae with variation of metabolite concentration between the $5^{\text {th }}, 6^{\text {th }}$ and $7^{\text {th }}$ day of this larval stage. Hemolymph of treated or control larvae were collected, pooled and analyzed by GC-MS. Metabolites in bold were detected and quantified in the hemolymph. A graphical representation in grey of the concentrations of these metabolites was added in order to show the variation from $5^{\text {th }}$ to $7^{\text {th }}$ day of the last larval instar. Original graphs can be found in supplementary data (supplementary data figure S1). Metabolites surrounded by a black frame have a significant decrease of concentration in comparison to control during the $6^{\text {th }}$ day of the last instar (see results Table 1).

Table 1. Comparison of metabolites concentrations in the hemolymph of DEHP treated larvae during the $5^{\text {th }}, 6^{\text {th }}$ and $7^{\text {th }}$ days of the last larval instar in comparison to control larvae. Only the metabolites showing a significant variation in comparison to control were presented in this table. ">" and "<" indicate that the measured concentration of the corresponding metabolite is respectively superior or inferior to control concentrations. Asterisks indicate significant differences among means in comparison to controls ( $* \mathrm{P}<0.05$; ** $\mathrm{P}<0.01$; *** $\mathrm{P}<0.001)$.

Table S1. Analytical conditions used for determination of DEHP content in S. littoralis adult males and females by GC-MS. IS: internal standard

Table S2. Sequences of the primers used for RTqPCR amplification in Spodoptera littoralis larvae. F: forward primer; R: reverse primer 
Table S3 Minimum and maximum metabolite concentrations and non-detected metabolites on the three days of GC-MS analysis in treated and control larvae. Concentrations were expressed in nmoles $/ \mu \mathrm{L}$ of hemolymph.

Figure S1. Metabolic variations in treated and control larvae during the $5^{\text {th }}, 6^{\text {th }}$ and $7^{\text {th }}$ day of the last larval stage. Hemolymph of treated and control larvae were collected, pooled and analyzed by GC-MS. Metabolite contents (nmoles. $\mu \mathrm{L}^{-1}$ of hemolymph) were expressed as means \pm SEM $(\mathrm{N}=10$ replicates for each experimental condition). 


\section{Figure 1}

A

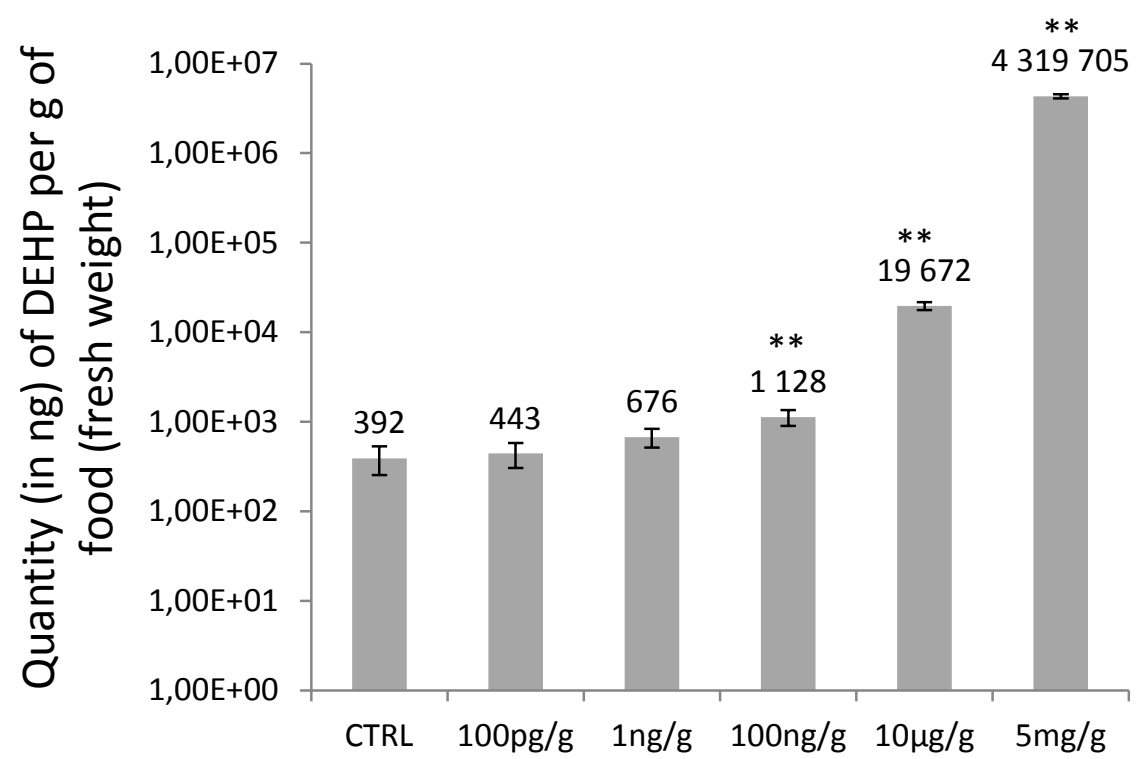

B

\begin{tabular}{|c|c|c|c|c|c|c|c|c|}
\hline Theoretical (per g of fresh food) & $100 \mathrm{pg}$ & $1 \mathrm{ng}$ & $100 \mathrm{ng}$ & $1 \mu \mathrm{g}$ & $10 \mu \mathrm{g}$ & $500 \mu \mathrm{g}$ & $5 \mathrm{mg}$ & $40 \mathrm{mg}$ \\
\hline $\begin{array}{c}\text { Measured(*) or estimated(e) by linear } \\
\text { regression (per g of fresh food) }\end{array}$ & $\begin{array}{c}443 \mathrm{ng} \\
(*)\end{array}$ & $\begin{array}{c}676 \mathrm{ng} \\
(*)\end{array}$ & $\begin{array}{c}1.1 \mu \mathrm{g} \\
(*)\end{array}$ & $\begin{array}{c}3.2 \mu \mathrm{g} \\
(\mathrm{e})\end{array}$ & $\begin{array}{c}19.7 \mu \mathrm{g} \\
(*)\end{array}$ & $\begin{array}{c}447.2 \mu \mathrm{g} \\
(\mathrm{e})\end{array}$ & $\begin{array}{c}4.3 \mathrm{mg} \\
(*)\end{array}$ & $\begin{array}{c}39.5 \mathrm{mg} \\
(\mathrm{e})\end{array}$ \\
\hline
\end{tabular}




\section{Figure 3}

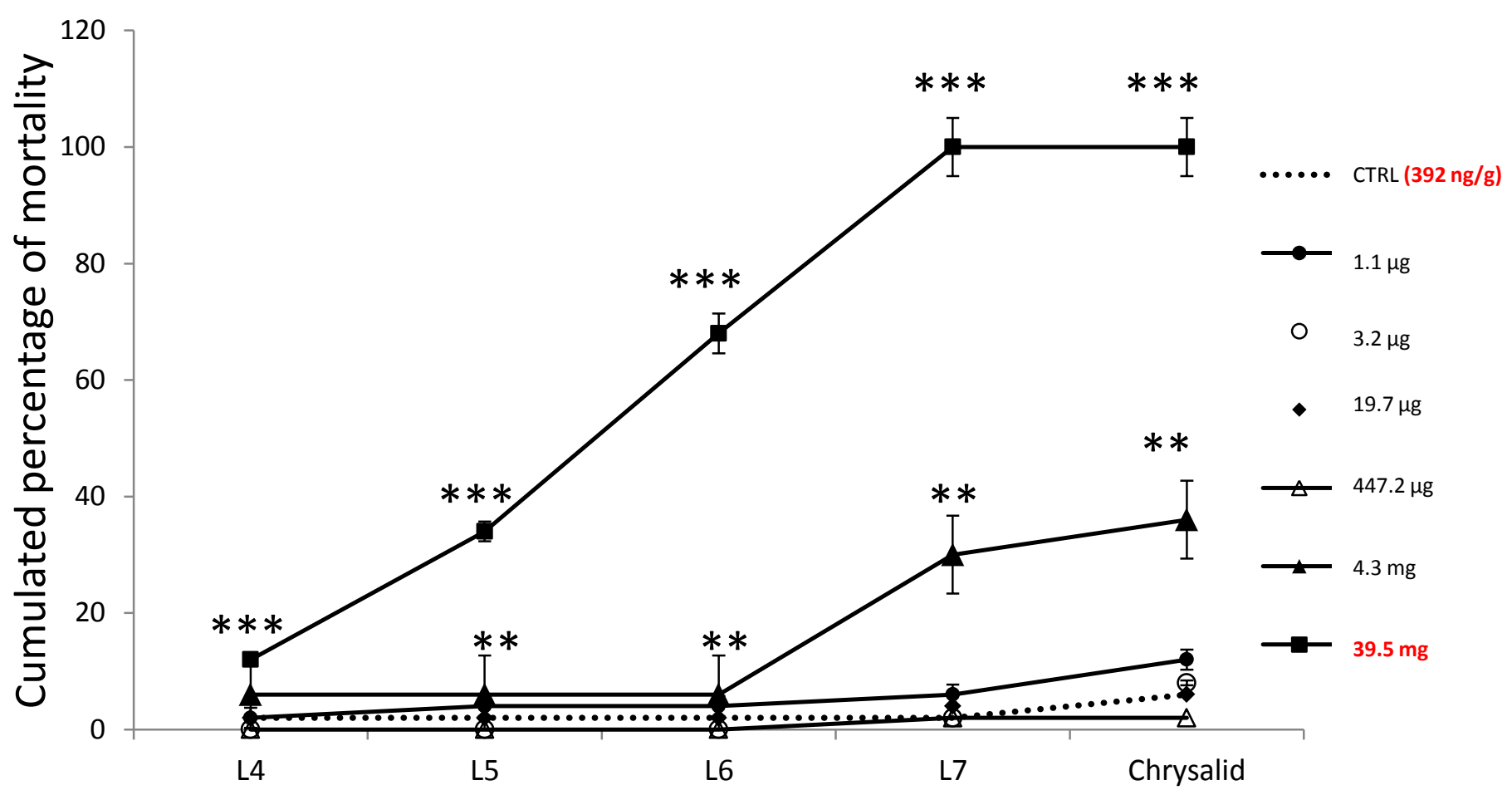


Figure 5

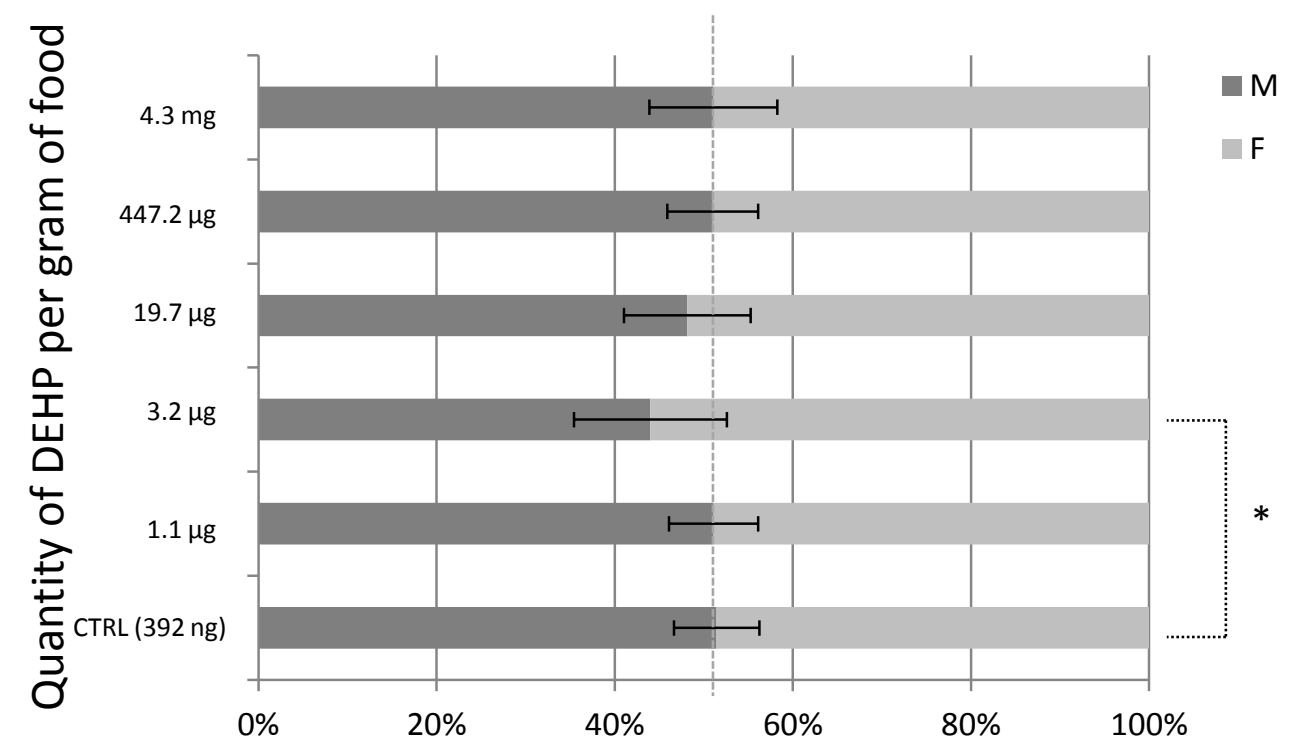


Figure 6

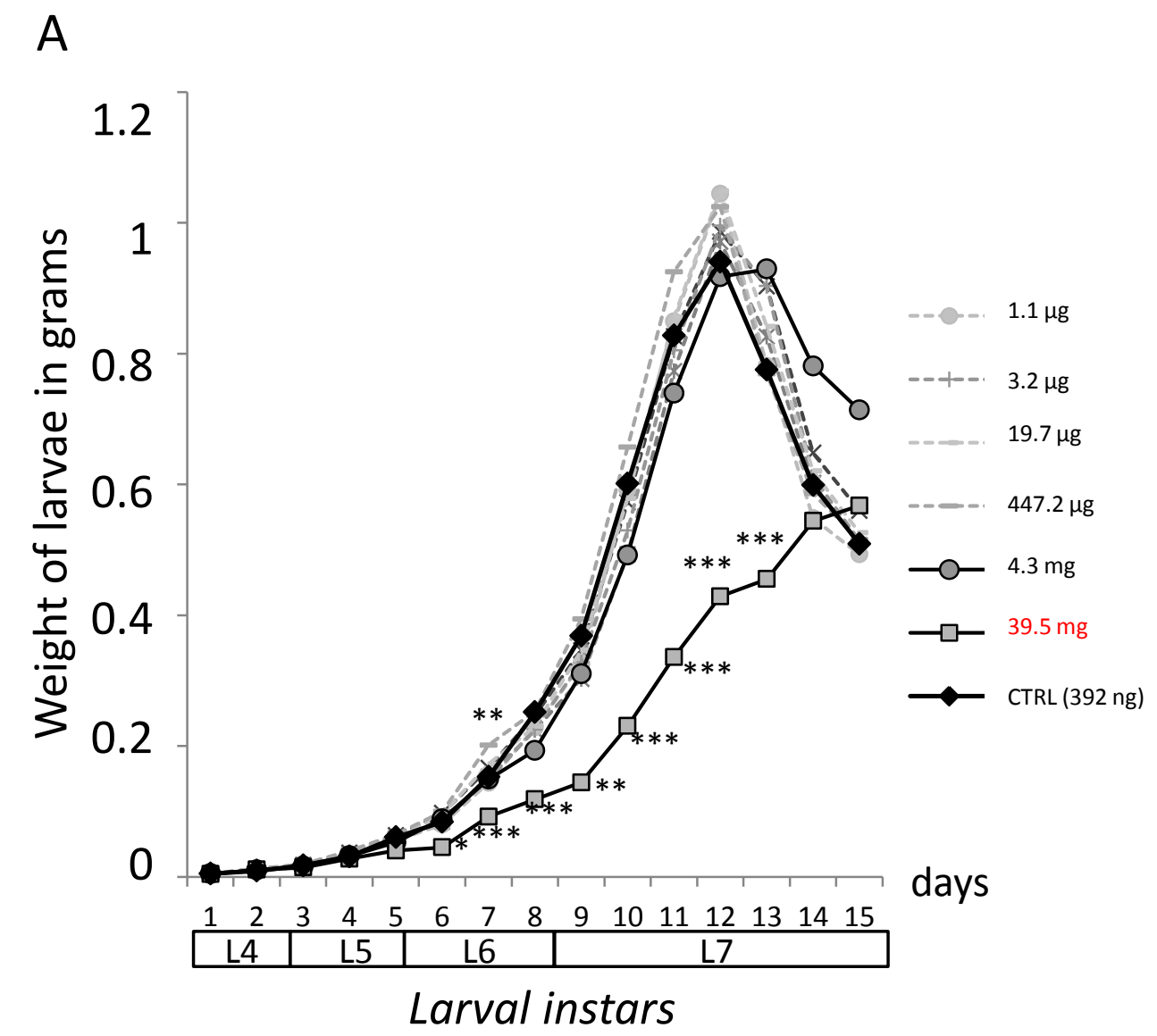

B

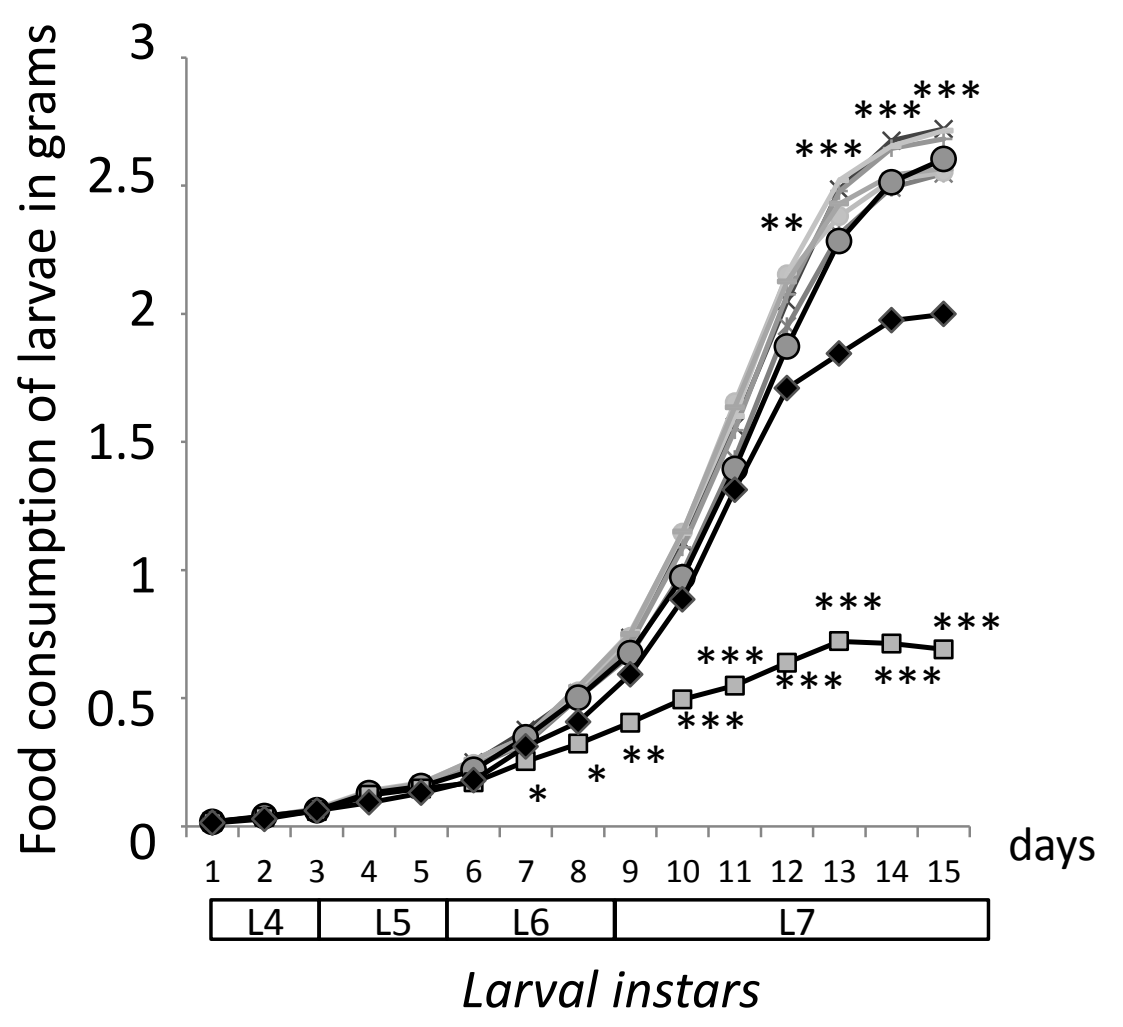


Figure 7

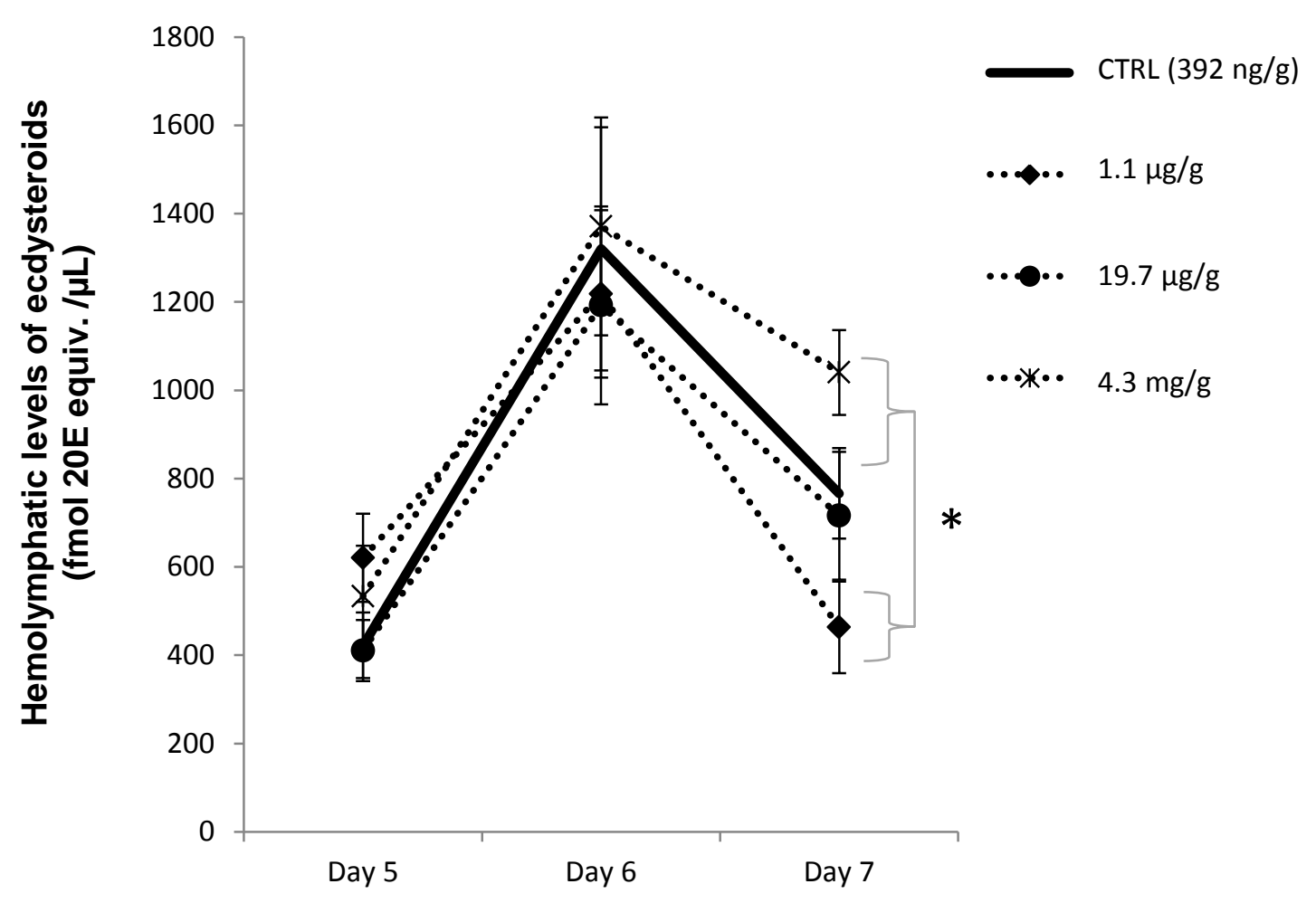


Figure 8

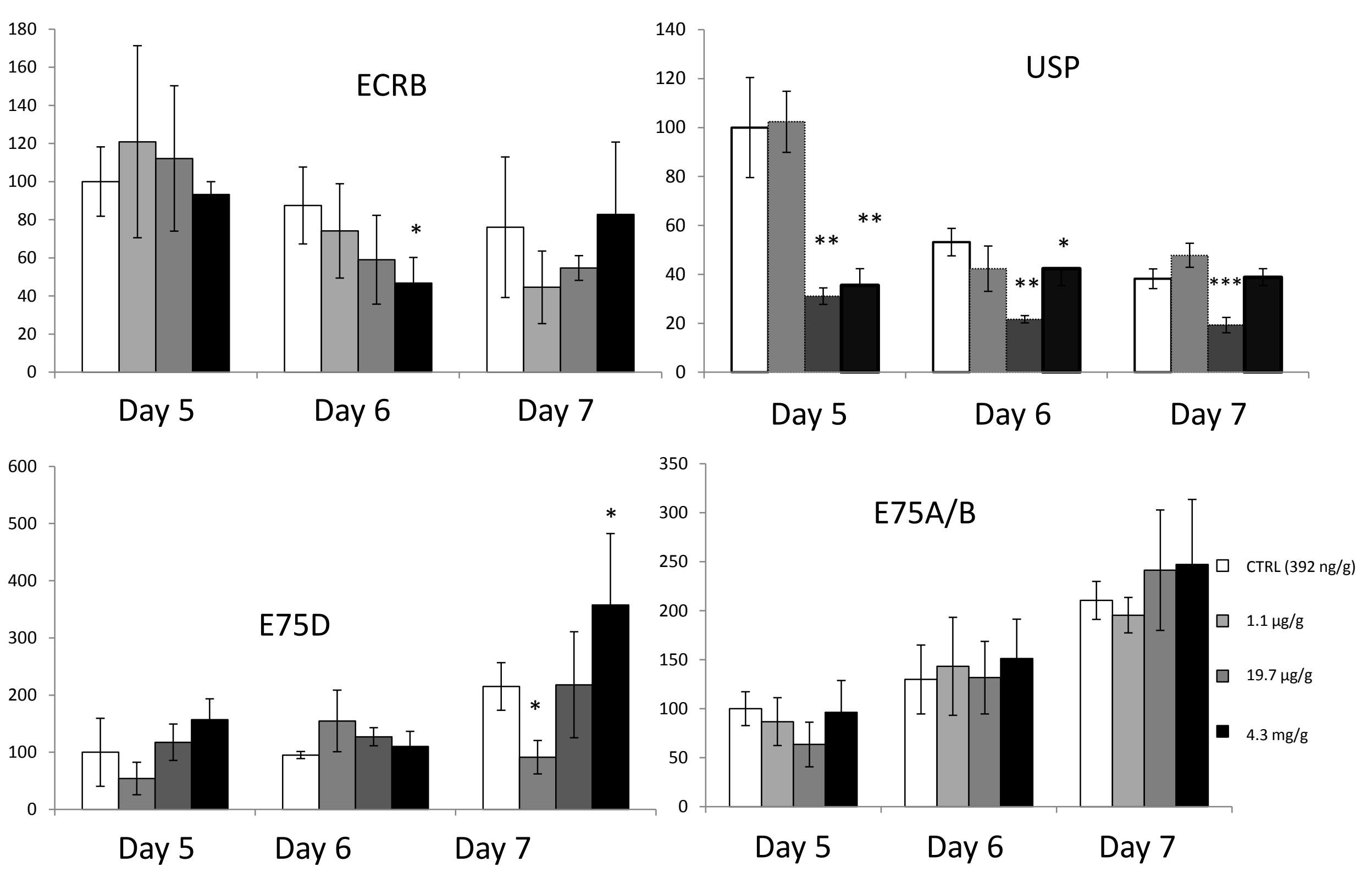




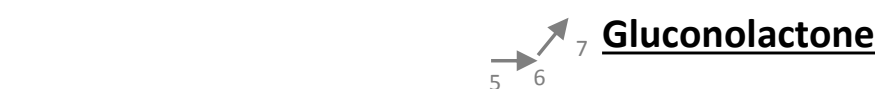

Glucose-1P $\longrightarrow$ Arabinose $\longrightarrow$ Arabitol

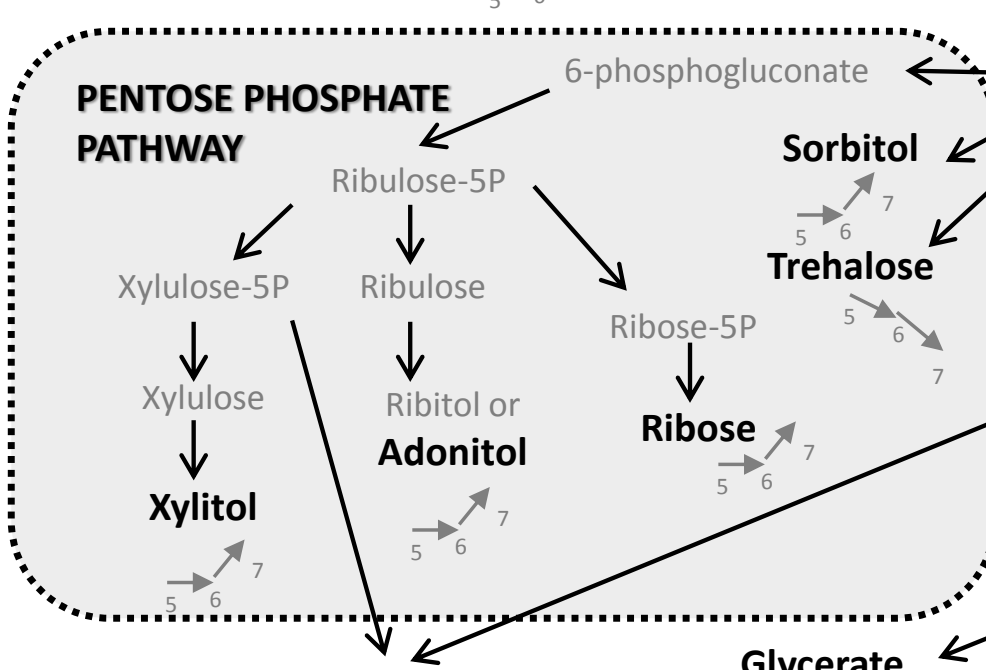

Erythritol $\leftarrow$ Erythrose $\leftarrow$ Erythrose-4P $\lambda_{6}$

FATTY ACIDS BIOSYNTHESIS

Galacturonic $\longrightarrow$ Glycerol acid

Glycerol-P Inositol

\section{Glycerate}

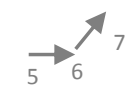
Phenylalanine

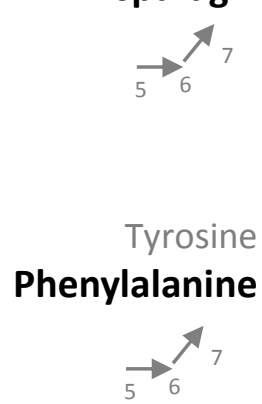

GLUCONEOGENESIS

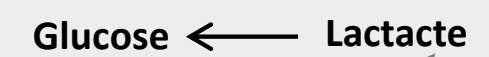

Glyceraldehyde-3P

1,3-biphosphoglycerate

3-phosphoglycerate

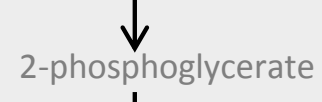

Fructose-6P

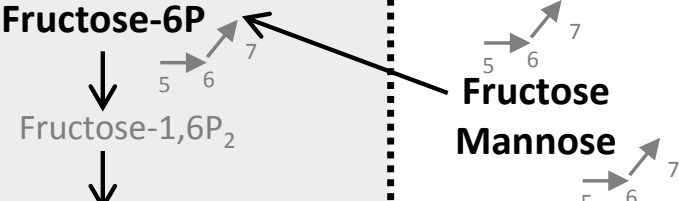

G

Galactose $\rightarrow$

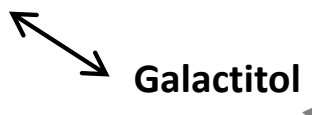

Serine

Glycine

Cysteine

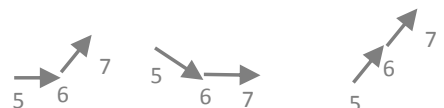

Alanine, Glycine, Threonine, Cysteine,

Serine, Tryptophan

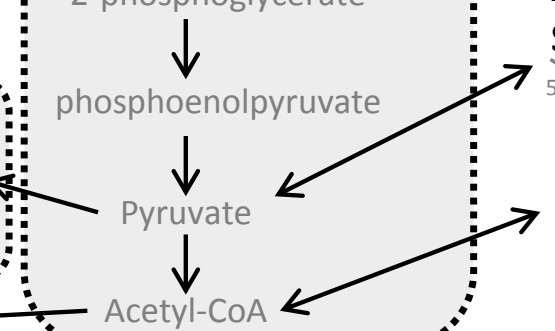

4

Aspartate

Asparagine

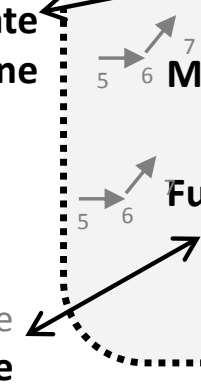

$\rightarrow$ Oxaloacetate

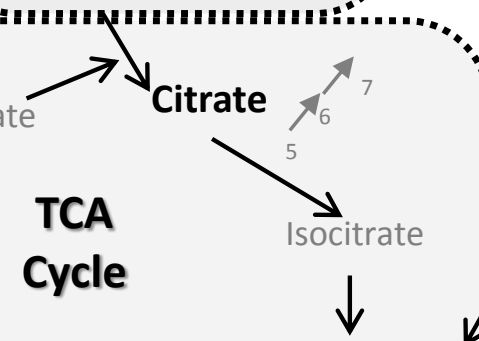

$\uparrow$

Cycle

Valine, Threonine, Isoleucine, Methionine

.7

2-ketoglutarate

Succinate
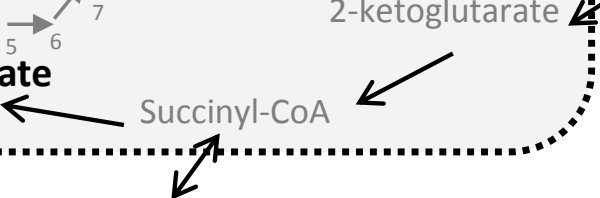

Leucine, Tyrosine, Phenylalanine,

Tryptophan, Lysine
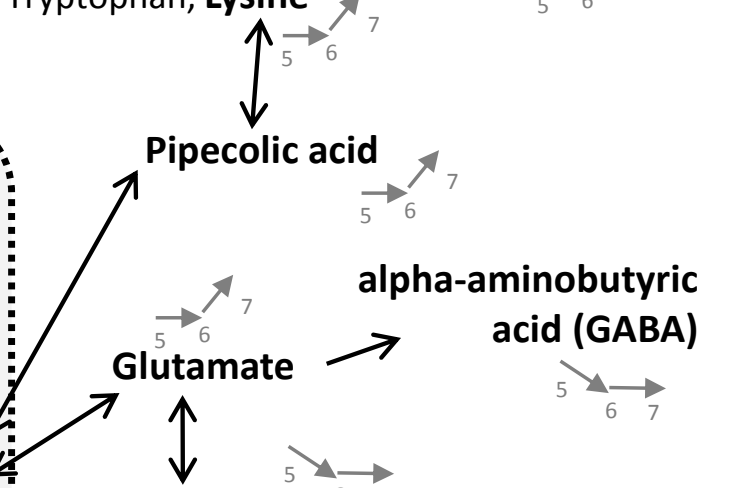

Glutamine, Proline, Histidine Arginine 


\begin{tabular}{|c|c|c|c|c|c|c|c|c|c|c|}
\hline & & \multicolumn{3}{|c|}{ Day 5} & \multicolumn{3}{|c|}{ Day 6} & \multicolumn{3}{|c|}{ Day 7} \\
\hline & & $1.1 \mu \mathrm{g} / \mathrm{g}$ & $19.7 \mu \mathrm{g} / \mathrm{g}$ & $4.3 \mathrm{mg} / \mathrm{g}$ & $1.1 \mu \mathrm{g} / \mathrm{g}$ & $19.7 \mu \mathrm{g} / \mathrm{g}$ & $4.3 \mathrm{mg} / \mathrm{g}$ & $1.1 \mu \mathrm{g} / \mathrm{g}$ & $19.7 \mu \mathrm{g} / \mathrm{g}$ & $4.3 \mathrm{mg} / \mathrm{g}$ \\
\hline Adonitol & Pentose Phosphate pathway & & & & $<*$ & & & & & \\
\hline Alanine & Amino acid synthesis & & & & $<*$ & $<*$ & & & & \\
\hline Asparagine & Amino acid synthesis & & & & $<*$ & & & & & \\
\hline Citric acid & TCA Cycle & & & & $<*$ & $<* *$ & & & & \\
\hline Fructose & Glycolysis & & & & $<*$ & & & & & \\
\hline Fumaric Acid & TCA Cycle & & & & $<*$ & & & & & \\
\hline Galacticol & Sugar alcohol synthesis & & & & $<*$ & & & & & \\
\hline Glyceric acid & Amino acid synthesis & & & & $<*$ & & & & & \\
\hline Glycerol & Fatty acids biosynthesis & & & & $<*$ & $<*$ & & & & \\
\hline Lactic Acid & Gluconeogenesis & & & & & & & & & $<*$ \\
\hline Leucine & Amino acid synthesis & & & & $<* *$ & & & & & \\
\hline Malic acid & TCA Cycle & & & & $<*$ & & & & & \\
\hline Phenylalanine & Amino acid synthesis & & & & $<*$ & & & & & \\
\hline Putrescine & Polyamine production & & & & $<* *$ & $<* *$ & & & & \\
\hline Serine & Amino acid synthesis & & & & & $<*$ & & & & \\
\hline Sorbitol & Pentose Phosphate pathway & & & & $<*$ & & & & & \\
\hline Succinic acid & TCA Cycle & & & & $<*$ & & & & & \\
\hline Threonine & Amino acid synthesis & & & & $<*$ & & & & & \\
\hline Trehalose & Pentose Phosphate pathway & & & & & & & & & $>*$ \\
\hline Valine & Amino acid synthesis & & & & $<*$ & $<*$ & & & & \\
\hline
\end{tabular}




\begin{tabular}{|c|c|c|c|c|c|c|c|}
\hline Injector & $\begin{array}{l}\text { Guard } \\
\text { column }\end{array}$ & Column & Oven & Helium & Detector & $\begin{array}{l}\text { Quantification (bold), } \\
\text { qualification (normal), } \\
\text { and IS (italic) }\end{array}$ & Reference \\
\hline $\begin{array}{l}290^{\circ} \mathrm{C} \\
1 \mu \mathrm{L}\end{array}$ & $\begin{array}{l}\text { Deactivate } \\
\text { d silica } \\
\text { pre-column } \\
\text { (1m; } \\
0.25 \mathrm{~mm} \mathrm{ID} \\
\text { from } \\
\text { Restek) }\end{array}$ & $\begin{array}{l}\text { ZB- } \\
\text { SemiVolatils } \\
(30 \mathrm{~m}, \\
250 \mu \mathrm{m} \text { film } \\
\text { thickness } \\
\text { from } \\
\text { Phenomene } \\
\text { x) }\end{array}$ & $\begin{array}{l}50^{\circ} \mathrm{C}(1 \\
\mathrm{min}) \\
30^{\circ} \mathrm{C} / \mathrm{min} \\
\text { to } 280^{\circ} \mathrm{C} \\
\text { then } \\
15^{\circ} \mathrm{C} / \mathrm{min} \\
\text { to } 310^{\circ} \mathrm{C} \text {, } \\
\text { held for } 4 \\
\text { min }\end{array}$ & $1 \mathrm{~mL} / \mathrm{min}$ & $\mathrm{El} 70 \mathrm{eV}$ & $\begin{array}{l}149,279 \\
153,171\end{array}$ & $\begin{array}{l}\text { (Teil et al., } \\
\text { 2013) }\end{array}$ \\
\hline
\end{tabular}




\begin{tabular}{|c|l|l|}
\hline $\begin{array}{c}\text { Primer } \\
\text { name }\end{array}$ & \multicolumn{1}{|c|}{ Description } & \multicolumn{1}{c|}{ DNA sequence (5' - $\mathbf{3}^{\prime}$ ) } \\
\hline EcRB & Ecdysone receptor & F TGCGAGGAAAAAGTGAAGTG \\
\hline & & R TTCCGGGGACATTACCATAG \\
\hline USP & Ultraspiracle & F CATGTCAGTGGCGAAGAAAG \\
\hline E75A/B & $\begin{array}{l}\text { Early response gene E75 } \\
\text { isoform A/B }\end{array}$ & F TGGACACCCTTCCTGATCTC \\
\hline E75D & $\begin{array}{l}\text { Early response gene E75 } \\
\text { isoform D }\end{array}$ & F GTTTCCGACATGGGAGAAGA \\
\hline & & R AGGGGCATCATCTAGCTCTG \\
\hline
\end{tabular}


Table S3

\begin{tabular}{|c|c|c|c|}
\hline Metabolites & $\begin{array}{l}\text { Minimum and maximum metabolite concentrations } \\
\text { ( } \mathrm{nmoles} / \mu \mathrm{L} \text { of hemolymph) }\end{array}$ & Metabolites & $\begin{array}{l}\text { Minimum and maximum metabolite } \\
\text { concentrations ( } \mathrm{nmoles} / \mu \mathrm{L} \text { of hemolymph) }\end{array}$ \\
\hline Adonitol & $0.65-12.84$ & Lysine & $0.78-193.46$ \\
\hline Alanine & $14.31-603.90$ & Malic acid & $117.43-1766.75$ \\
\hline Arabinose & Non detected < LQ $(5 \mu \mathrm{M})$ & Mannose & $0.14-13.14$ \\
\hline Arabitol & $0.74-4.31$ & Melezitose & Non detected < LQ $(5 \mu \mathrm{M})$ \\
\hline Asparagine & $58.36-725.04$ & Melobiose & Non detected < LQ $(5 \mu \mathrm{M})$ \\
\hline Aspartic acid & $6.89-37.32$ & Phenylalanine & $8.03-153.18$ \\
\hline Cadaverine & Non detected < LQ $(5 \mu \mathrm{M})$ & Phosphoric acid & $9.47-219.82$ \\
\hline Citric acid & 467.12 - 1984.26 & Pipecolic acid & $0.65-1.66$ \\
\hline Citrulline & Non detected < LQ $(5 \mu \mathrm{M})$ & Proline & $25.48-784.13$ \\
\hline Dopamine & Non detected < LQ $(5 \mu \mathrm{M})$ & Putrescine & $13.17-179$ \\
\hline Erythrol & $0.16-3.25$ & Ornithine & Non detected < LQ $(5 \mu \mathrm{M})$ \\
\hline Ethanolamine & Non detected < LQ $(5 \mu \mathrm{M})$ & Quinic acid & $0.65-0.74$ \\
\hline Fructose & Non detected $<\mathrm{LQ}(5 \mu \mathrm{M})-22.85$ & Raffinose & Non detected < LQ $(5 \mu \mathrm{M})$ \\
\hline Fructose 6P & Non detected < LQ $(5 \mu \mathrm{M})-25.86$ & Ribose & $4.63-17.44$ \\
\hline Fumaric Acid & $12.93-735.59$ & Saccharose & Non detected < LQ $(5 \mu \mathrm{M})$ \\
\hline Galacticol & $2.38-10.07$ & Serine & $14.56-566$ \\
\hline Galactose & $0.12-14.31$ & Sorbitol & $2.40-28.50$ \\
\hline alacturonic acid & Non detected < LQ $(5 \mu \mathrm{M})-10.50$ & Spermidine & Non detected $<\mathrm{LQ}(5 \mu \mathrm{M})-55.80$ \\
\hline nminobutyric acid & $0.90-42.13$ & Spermine & Non detected < LQ $(5 \mu \mathrm{M})$ \\
\hline Gentobiose & Non detected < LQ $(5 \mu \mathrm{M})$ & Succinic acid & $41.18-1194.87$ \\
\hline conic lactone acid & $0.54-441.23$ & Threonine & $9.50-357.98$ \\
\hline Glucose & $1.82-712.40$ & Trehalose & $3.45-1209.93$ \\
\hline Glucose 6P & Non detected < LQ $(5 \mu \mathrm{M})-11.50$ & Triethanolamine & Non detected < LQ $(5 \mu \mathrm{M})$ \\
\hline Glutamic acid & $15.91-532.64$ & Tryptophane & Non detected < LQ $(5 \mu \mathrm{M})$ \\
\hline Glutamine & Non detected < LQ $(5 \mu \mathrm{M})$ & Uric Acid & Non detected < LQ $(5 \mu \mathrm{M})$ \\
\hline Glyceric acid & $0.61-29.30$ & Valine & $12.46-367.06$ \\
\hline Glycerol & $3.83-603.45$ & Xylitol & $2.04-15.86$ \\
\hline Glycerol P & $33.09-1989.48$ & Xylose & Non detected < LQ $(5 \mu \mathrm{M})$ \\
\hline Glycine & $1.57-238.97$ & & \\
\hline Inositol & $0.66-191.35$ & & \\
\hline Isoleucine & $8.96-197.27$ & & \\
\hline Lactic Acid & $2.47-57.25$ & & \\
\hline Leucine & $9.94-317.30$ & & \\
\hline Lysine & $0.78-193.46$ & & \\
\hline
\end{tabular}


Supplementary data Figure S1

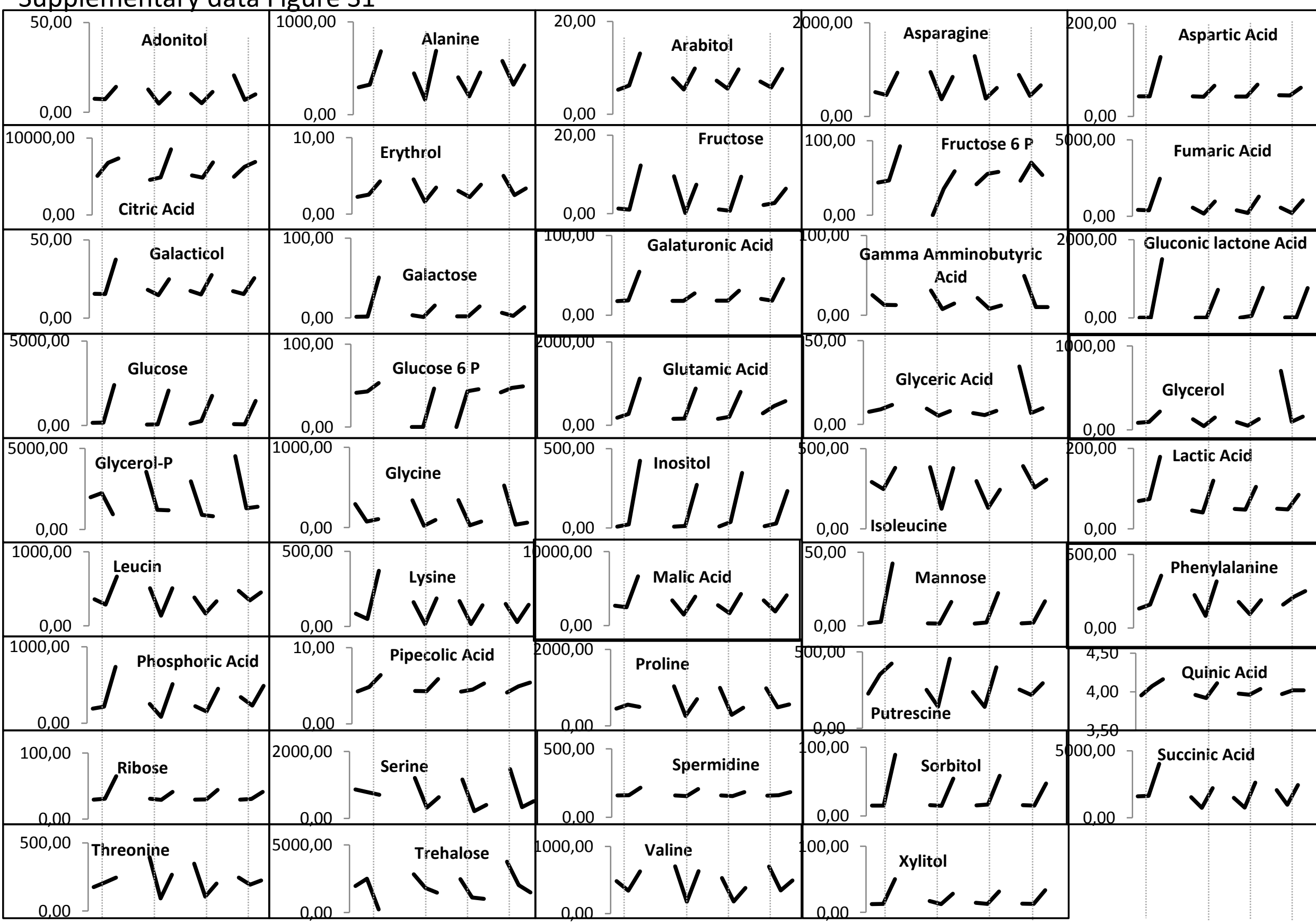




\section{$\underline{\text { Highlights }}$}

(1) DEHP was shown to be present both in larvae and resulting stages, with higher concentrations in chrysalises and adults than in larvae.

(2) DEHP concentrations also decreased at the end of the last larval instar, suggesting the metabolic transformation or excretion of this chemical during this time.

(3) Only the two highest DEHP doses induced higher insect mortality, whereas low and intermediate concentrations increased larval food consumption without affecting body weight.

(4) DEHP treatments also alter both hemolymphatic ecdysteroid titers and expression levels of ecdysteroid response genes.

(5) DEHP can alter insect post-embryonic development and metamorphosis, by interfering with ecdysteroid pathways. 